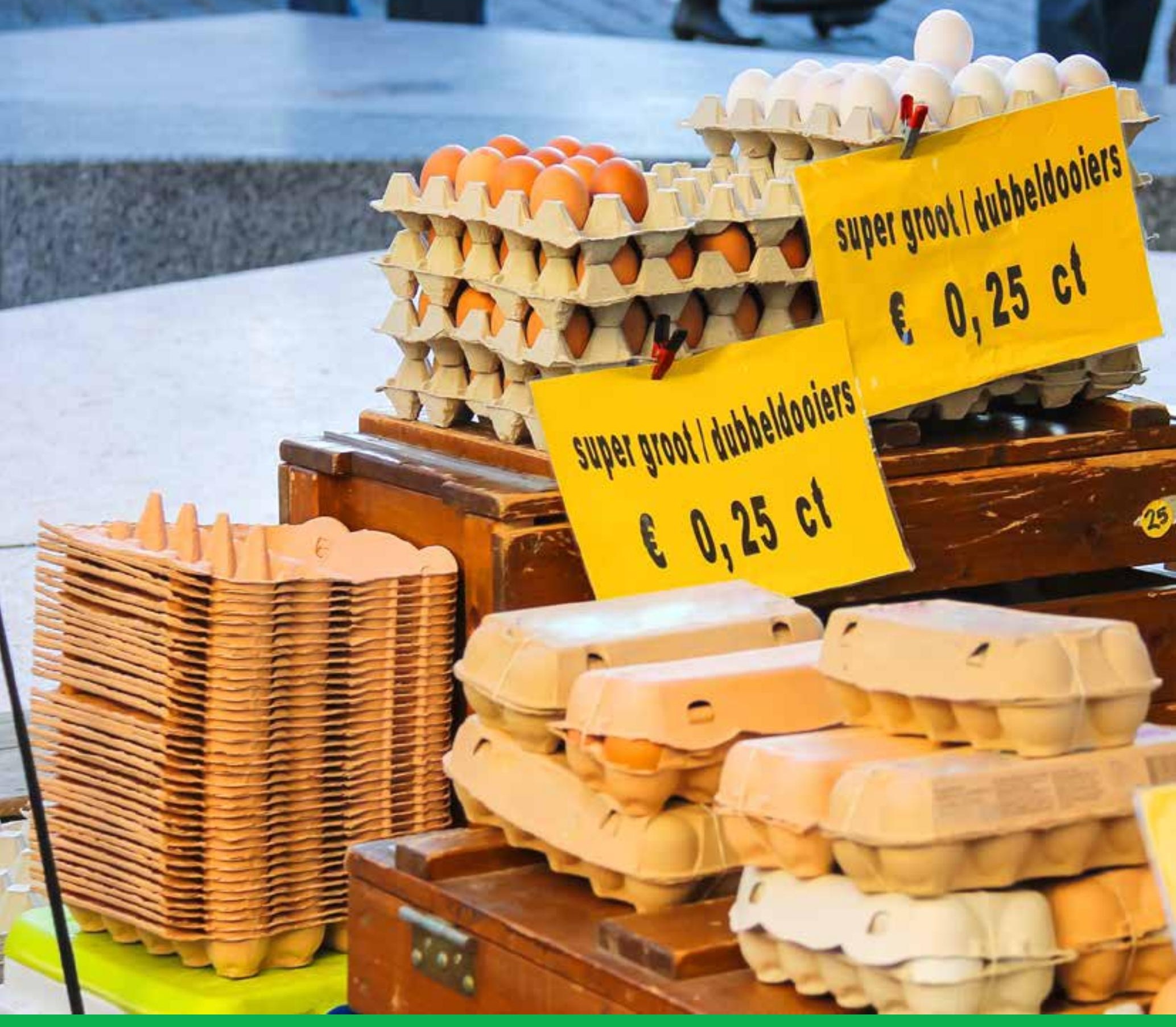

Korte Ketens in Gelderland

J.W. van der Schans en D. van Wonderen

WAGENINGEN

UNIVERSITY \& RESEARCH 



\section{Korte ketens in Gelderland}

J.W. van der Schans en D. van Wonderen

Dit onderzoek is uitgevoerd door Wageningen Economic Research in opdracht van en gefinancierd door de Provincie Gelderland

Wageningen Economic Research

Wageningen, juli 2019

NOTA

2019-072 
Schans J.W. van der en D. van Wonderen, 2019. Korte Ketens in Gelderland. Wageningen, Wageningen Economic Research, Nota 2019-072. 40 blz.; 22 fig.; 0 tab.; 10 ref.

Dit rapport geeft een beeld van de omvang en verspreiding van korte voorzieningsketens voor landbouwproducten in de provincie Gelderland. Allereerst wordt gedefinieerd wat korte voorzieningsketens zijn, in de context van het Gemeenschappelijk landbouwbeleid. Vervolgens is gekeken wat de omvang van korte voorzieningsketens is in Gelderland: welke sectoren lopen voorop, welke gemeenten lopen voorop? Ook is gekeken welke aanvullende kenmerken bedrijven hebben die in korte voorzieningsketens actief zijn: qua bedrijfsgrootte, opvolgingssituatie, etc. Ook is onderzocht welke verbanden er zijn tussen korte voorzieningsketens en verbrede landbouw. Ten slotte is een beeld gegeven van de dynamiek van korte voorzieningsketens, in het bijzonder huisverkoop.

This report provides a picture of the size and distribution of short supply chains for agricultural products in the Province of Gelderland. First we define short food supply chains in the context of the Common Agricultural Policy. Then we look at the size of short food supply chains in Gelderland: which sectors and municipalities are taking the lead? Furthermore, some additional attributes of short food supply chains have been analysed: farm size, whether or not there is a successor for the farm, etc. The relations between multi-functional farming activities and short food supply chains have also been analysed. Lastly, the dynamics of farm sales have been analysed, as an example of a short food supply chain which is relatively well documented.

Trefwoorden: korte voorzieningsketens, short food supply chains, plattelandsontwikkelingsbeleid, POP3

Dit rapport is gratis te downloaden op https://doi.org/10.18174/495050 of op www. wur. nl/economicresearch (onder Wageningen Economic Research publicaties).

(C) 2019 Wageningen Economic Research

Postbus 29703, 2502 LS Den Haag, T 07033583 30, E communications.ssg@wur.nl, www. wur.nl/economic-research. Wageningen Economic Research is onderdeel van Wageningen University \& Research.

\section{(cc) BY-NC}

Dit werk valt onder een Creative Commons Naamsvermelding-Niet Commercieel 4.0 Internationaallicentie.

(C) Wageningen Economic Research, onderdeel van Stichting Wageningen Research, 2019 De gebruiker mag het werk kopiëren, verspreiden en doorgeven en afgeleide werken maken. Materiaal van derden waarvan in het werk gebruik is gemaakt en waarop intellectuele eigendomsrechten berusten, mogen niet zonder voorafgaande toestemming van derden gebruikt worden. De gebruiker dient bij het werk de door de maker of de licentiegever aangegeven naam te vermelden, maar niet zodanig dat de indruk gewekt wordt dat zij daarmee instemmen met het werk van de gebruiker of het gebruik van het werk. De gebruiker mag het werk niet voor commerciële doeleinden gebruiken.

Wageningen Economic Research aanvaardt geen aansprakelijkheid voor eventuele schade voortvloeiend uit het gebruik van de resultaten van dit onderzoek of de toepassing van de adviezen.

Wageningen Economic Research is ISO 9001:2008 gecertificeerd. 


\section{Inhoud}

$\begin{array}{ll}\text { Woord vooraf } & 5\end{array}$

$\begin{array}{ll}\text { Korte ketens in Gelderland } & 6\end{array}$

$\begin{array}{ll}\text { Doel van het onderzoek } & 7\end{array}$

Definitie korte ketens is niet eenduidig

$\begin{array}{lr}\text { Onderzoeksmethode } & 10\end{array}$

EU-beleid en Nederlandse insteek ten aanzien van korte ketens 



\section{Woord vooraf}

Korte voorzieningsketens spelen een steeds belangrijkere rol in het Provinciale plattelandsontwikkelingsbeleid. Niet zozeer als doel op zich maar als manier om andere doelen te bereiken, zoals het creëren van meer waardering (economisch en moreel) voor de producten van boeren en tuinders. In de Landbouwtelling van 2017 liep op initiatief van Wageningen Economic Research een vraag mee over korte ketens. We zijn erg blij dat de Provincie Gelderland ons in de gelegenheid heeft gesteld de verkregen data te analyseren. We gaan ervan uit dat een dergelijke analyse niet alleen voor Gelderland relevant is maar ook voor andere Provincies. En ook voor de landelijke overheid, die immers samen met de provincies verantwoordelijk is voor het vormgeven en uitvoeren van het Europese plattelandsbeleid.

We danken de boeren en tuinders voor het invullen van de vragenlijst behorende bij de Landbouwtelling, want alleen zo kunnen we een getrouw beeld blijven geven van de ontwikkeling van korte (en lange) voorzieningsketens.

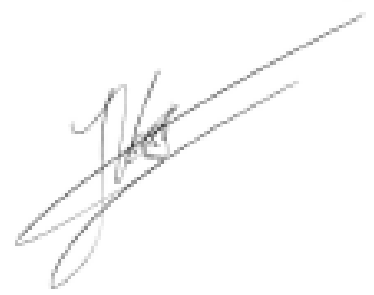

Prof.dr.ir. J.G.A.J. (Jack) van der Vorst Algemeen Directeur Social Sciences Group (SSG)

Wageningen University \& Research 


\section{$1 \quad$ Korte ketens in Gelderland}

De provincie Gelderland wil het landelijk gebied economisch en sociaal vitaal houden. Innovaties om de landbouw concurrerend te houden of te maken zijn hiervoor noodzakelijk. Korte voorzieningsketens spelen hierbij een speciale rol. De Provincie Gelderland ondersteunt korte voorzieningsketens via het Plattelandsontwikkelingsprogramma 2014-2020 (POP3), met name via de subsidieregeling: Samenwerking voor innovaties op lokaal niveau - Korte voorzieningsketens.

Uniek aan de Gelderse aanpak is dat alleen projecten gegund worden als de indienende landbouwer een streekproducent is en één of meer gemeenten meedoen. Inmiddels is er een provinciaal stedennetwerk ontstaan dat diverse keren per jaar bij elkaar komt om ervaringen uit te wisselen en vorderingen te bespreken. Ook zijn concrete projecten opgestart in het kader van de POP3 en Agenda Vitaal Platteland. Zo is er een Masterclass Produceren in de Korte Keten georganiseerd in Ede en Barneveld en ook in Rivierenland. Hierbij werd in diverse bijeenkomsten ondersteuning geboden aan boeren om hun afzetketens te verkorten en zich meer te richten op de regionale markt. Ook is Gelderland als enige provincie actief in het landelijk netwerk van steden die voedsel op de agenda hebben gezet: de City-deal 'Voedsel op de stedelijke agenda'. Gelderland zegt daarin onder andere toe de lessen rond het provinciaal stedennetwerk uit te dragen, POP3-middelen in te zetten ten behoeve van korte ketens en de City-deal breed onder de aandacht te brengen, ook bij andere provincies. Voor de toekomst onderzoekt Gelderland haar rol naar de consumenten.

De provincie Gelderland zet via de genoemde initiatieven sterk in op het thema korte voorzieningsketens. Zowel in het kader van een vitaal platteland als ten behoeve van de vitaliteit van steden en regio's. In 2017 heeft op initiatief van het (landelijk opererend) POP3-regiebureau nog een kwalitatieve inventarisatie plaatsgevonden van korteketeninitiatieven, ook in Gelderland. ${ }^{1}$ Met de toenemende beleidsinzet neemt binnen de provincie ook de behoefte toe aan meer kwantitatief inzicht in de effectiviteit van het provinciaal beleid. In welke sectoren en in welke Gelderse regio's slaan korte ketens aan, en waar lopen ze achter? Wat is de dynamiek door de jaren heen, neemt het marktaandeel van korte ketens inderdaad toe? Dragen korte ketens inderdaad bij aan een verduurzaming van ons voedselsysteem? Hoe doet Gelderland het ten opzichte van andere provincies in Nederland en is de keuze om juist te interveniëren via steden (waar zich het grootste deel van de consumenten bevindt) inderdaad de juiste gebleken?

Voor de beantwoording van deze vragen met betrekking tot de effectiviteit van beleid is dus ook kwantitatief onderzoek nodig, bij voorkeur in meerdere provincies, over meerdere jaren en in meerdere sectoren. Om dit type onderzoek mogelijk te maken heeft Wageningen Economic Research, in samenspraak met het ministerie van LNV, in 2016 het initiatief genomen om een vraag over korte ketens mee te laten lopen in de Landbouwtelling (RVO) over het jaar 2017. Tot nu toe ontbrak op nationaal niveau budget om de gegeven antwoorden op deze vraag systematisch te analyseren.

1 http://www.deschaalvankampen.nl/korte-ketens-in-gelderland/ 


\section{Doel van het onderzoek}

De Provincie Gelderland heeft, gezien de beleidsrelevantie van het onderwerp korte ketens, aan Wageningen Economic Research gevraagd op basis van de Landbouwtelling 2017 voor de Provincie Gelderland een kwantitatieve analyse te maken van de omvang van en de dynamiek in de korte ketens in Gelderland. 


\section{Definitie korte ketens is niet eenduidig}

Volgens Verordening (EU) nr. 1305/2013 inzake steun voor plattelandsontwikkeling betekent een 'korte toeleveringsketen' een toeleveringsketen bestaande uit een beperkt aantal marktdeelnemers die streven naar samenwerking, plaatselijke economische ontwikkeling en nauwe geografische en sociale betrekkingen tussen producenten, verwerkers en consumenten (artikel $2 \mathrm{~m}$ ). De Commissie heeft het begrip korte keten verder gespecificeerd in gedelegeerde regelgeving (Delegated Regulation 11.03.2014). Deze regeling geeft aan dat ondersteuning voor het opzetten en ontwikkelen van korte ketens alleen toeleveringsketens dekt met niet meer dan één intermediair tussen landbouwer en consument (Commission 2014, Article 11).

Het gaat dus om geen of maximaal één ketenpartij tussen boer en consument. Deze definitie gaat verder dan rechtstreekse verkoop van boeren aan eindconsumenten. De EU-definitie laat toe dat er maximaal één tussenschakel actief is: een handelaar, verwerker of distributeur. Daarmee is deze definitie ruimer dan die gehanteerd wordt in Nederland in het kader van de multifunctionele landbouw:

'Multifunctionele landbouw is een verzamelbegrip voor bedrijven die hun agrarische productie en omgeving combineren met het leveren van diensten aan de samenleving: zorglandbouw, boerderijeducatie, boerderijwinkels/korte ketens, agrarische kinderopvang, agrarisch natuurbeheer en agrotoerisme. Bij al deze diensten gaat het om de relatie tussen de boerderij en burgers/consumenten. Multifunctionele landbouw is dus het (her)verbinden van de landbouw en de samenleving. ${ }^{2}$

Deze subtiele verschuiving in definitie (van nul schakels tot maximaal één schakel) hangt samen met veranderingen van doelstelling. Ging het bij multifunctionele landbouw om herstel van een directe relatie tussen boeren en burgers, bij korte ketens gaat het om het versterken van de economische positie van boeren, zodat ze beter in staat zijn aan maatschappelijke wensen te voldoen. Daar passen ook activiteiten bij die de plattelandseconomie verrijken, maar niet voor eindconsumenten uitgevoerd worden, zoals aanneemwerk in de wegenbouw, het groenbeheer, en het tot waarde brengen van biomassa (allemaal business-to-business-activiteiten). Daar past ook een rol bij van tussenschakels die de boeren werk uit handen nemen zonder zich een onevenredig deel van de marge toe te eigenen. Denk aan een handelaar die efficiënt goederenstromen bundelt, een bakker die van het meel eerst brood bakt of een slager die het vee eerst tot pakketten vlees verwerkt waar eindconsumenten mee uit de voeten kunnen.

De Gelderse initiatieven 'Oregional', 'Boerenhart' en 'Local2Local' worden algemeen gezien als voorbeelden van korte ketens. Als we louter tussenschakels tellen dan vallen deze initiatieven echter strikt genomen niet altijd onder de EU-definitie van korte ketens. Dit omdat deze intermediaire organisaties vaak doorleveren aan supermarkten of horeca. Dit maakt het totaal aantal schakels tussen producent en consument twee, of zelfs meer. Boerenhart leverde bijvoorbeeld ook aan de groothandel, die vervolgens weer aan de horeca leverde. Local2local doet dat nog steeds. Anderzijds gaat het zowel bij Boerenhart als Oregional om coöperaties die mede in handen van de deelnemende boeren zijn, waarbij soms zelfs de financiering van de coöperatie plaatsvond op basis van zekerheden bij de deelnemende boeren. Hoewel de boeren die aan Boerenhart of Oregional leveren een rekening sturen, kunnen deze coöperaties als een verlengstuk van de deelnemende boerenbedrijven worden gezien.

Het moge duidelijk zijn dat de EU-definitie van korte ketens haar beperkingen heeft. Het tellen van het aantal tussenschakels geeft niet altijd een goed beeld van de achterliggende beleidsdoelen die we proberen te bereiken met korte ketens. De EIP-Agri Focus Group omschrijft korte ketens dan ook met de volgende begrippen: 'zo min mogelijk schakels, transparant, eerlijk, op basis van partnerschap'

2 https://www.wur.nl/nl/Dossiers/dossier/Multifunctionele-landbouw-1.htm 
(EIP-Agri 2015, box 1, p.6). Wie deze definitie hanteert, kijkt veeleer naar wat korte ketens daadwerkelijk doen (bijvoorbeeld in termen van herverdeling marge in de keten) dan te tellen hoeveel schakels er zitten tussen landbouwer en eindconsument.

Samengevat kunnen we stellen dat de EU-definitie van korte ketens formalistisch is. Je kunt vrij makkelijk tellen hoeveel tussenschakels er zijn. De definitie van de EIP Focus Group is meer inhoudelijk. Deze gaat over de achterliggende doelen van korte ketens. De huidige minister van LNV vindt korte ketens interessant omdat ze de belofte in zich hebben van zowel een hoger inkomen als meer waardering voor de boer. Het gaat de minister dus ook om de achterliggende doelen, eerder dan het aantal tussenschakels te beperken tot maximaal één.

Tenslotte merken we op dat met 'producten uit korte ketens' en 'streekproducten' niet altijd hetzelfde bedoeld wordt. Via korte ketens probeert een regio niet alleen unieke streekproducten, maar juist ook het brede scala aan verse producten (al dan niet unieke streekgebonden variëteiten) toegankelijk te maken binnen de eigen regio. Streekproducten zijn karakteristieke producten voor een bepaalde streek, die weliswaar soms binnen die streek geconsumeerd worden (hopelijk in een korte keten met niet meer dan één schakel tussen boer en consument), maar vaak juist ook buiten de streek als unieke producten te koop aangeboden worden (zonder expliciet het aantal tussenschakels te beperken). Ook streekproducten hebben als doel het inkomen van boeren te vergroten. Vandaar ook dat er Europese bescherming is voor, en ondersteuning van, streekproducten. De Europese oorsprongsbescherming kent drie versies. Beschermde Oorsprongsbenaming (BOB): productie, verwerking en bereiding vinden plaats binnen een bepaald geografisch gebied. Beschermde Geografische Aanduiding (BGA): minimaal één van de productie-, verwerkings- of bereidingsstadia kunnen worden toegeschreven aan de geografische oorsprong. Gegarandeerde Traditionele Specialiteit (GTS): verwijst niet naar de herkomst, maar naar de traditionele productsamenstelling of productiemethode. ${ }^{3}$ De gedachte is dat deze oorsprongsgaranties op zich voldoende zouden zijn om meerwaarde voor de boeren op te leveren. Bij korte ketens worden evenwel ook eisen gesteld aan de organisatie van de keten, er moet sprake zijn van zo min mogelijk tussenschakels en een vorm van partnerschap (transparantie, eerlijke verdeling van kosten en baten).

3 http://streekproductenloket.nu/merken/keurmerken/europese-oorsprongsbescherming 


\section{$4 \quad$ Onderzoeksmethode}

De Europese definitie van korte ketens (maximaal één tussenschakel) werd, voor het eerst, ook gebruikt bij de Landbouwtelling in 2017. Het ging om de vraag of de boer rechtstreeks of via één tussenschakel producten levert aan de consument. Deze vraag kon met ja, nee of niet bekend beantwoord worden. Vervolgens was de vraag om welk aandeel van de bedrijfsomzet het gaat. Deze vraag kon beantwoord worden via een keuze uit vier klassen: $<10 \%, 10-30 \%, 30-50 \%$ en $>50 \%$.

De vraag is evenwel of alle boeren begrepen hebben wat hier bedoeld is met 'korte keten', ook al was de uitleg op de RVO-website helder. We hebben dit getoetst door aan de deelnemers aan de Masterclass Produceren in de Korte Keten (versie Ede Barneveld 2018-2019, en versie Rivierenland 2018-2019) te vragen hoe zij deze vraag hebben ingevuld. Hieruit bleek dat de meeste boeren, zelfs die geïnteresseerd zijn in korte ketens, niet verder kijken dan de schakel die de spullen van het erf ophaalt. Als dat bijvoorbeeld de Coöperatie Boerenhart is (https://www.boerenhart.nl/), die zich met name richt op streekproducten uit de Gelderse Vallei, dan gaan zij ervan uit dat dit een korte keten is, en kijken ze niet verder naar waar deze producten precies belanden. Dit terwijl Boerenhart zoals gezegd meestal ketens betreft met twee tussenschakels (Boerenhart en een horecaonderneming of supermarkt), en daarmee buiten de definitie zou vallen. Anderzijds beantwoordden boeren die niet zelf aan de consument leverden de vraag soms met 'nee', zonder zich te realiseren dat levering via één tussenschakel ook telt als korte keten. Het valt te verwachten dat als korte ketens als beleidsinstrument serieuzer genomen worden, en de korteketenvraag in de Landbouwtelling vaker gesteld wordt, deze steeds nauwkeuriger beantwoord zal worden.

Daar waar nodig zijn gegevens geanonimiseerd: als een klasse minder dan tien waarnemingen bevat wordt deze niet gerapporteerd. 


\section{$5 \quad$ EU-beleid en Nederlandse insteek ten aanzien van korte ketens}

Korte ketens en lokale markten worden ook ondersteund door het Gemeenschappelijk Landbouw Beleid. Ze vallen onder focusgebied 3A, samen met kwaliteitsprogramma's en producentenorganisaties. Landen als Spanje, Cyprus, Oostenrijk, Hongarije en Finland hebben als expliciete doelstelling dat meer dan $5 \%$ van de bedrijven steun op dit focusgebied moet hebben gehad (figuur 5.1). Landen als Slowakije en Hongarije hebben zich vastgelegd om 16,3\% respectievelijk $16,1 \%$ van het POP3-budget hieraan te spenderen (figuur 5.2).

Nederland, Denemarken en Ierland hebben de ondersteuning van korte ketens niet geactiveerd (de grijs gekleurde landen in de figuur). Het gaat om EU-lidstaten met een uitgesproken landbouwbeleid gericht op de export. Dit betekent niet dat er in deze landen geen korte ketens ondersteund worden, maar wel dat dit geen expliciete doelstelling is waar men zich op vastgelegd heeft, waarop gemonitord, gerapporteerd en geëvalueerd wordt.

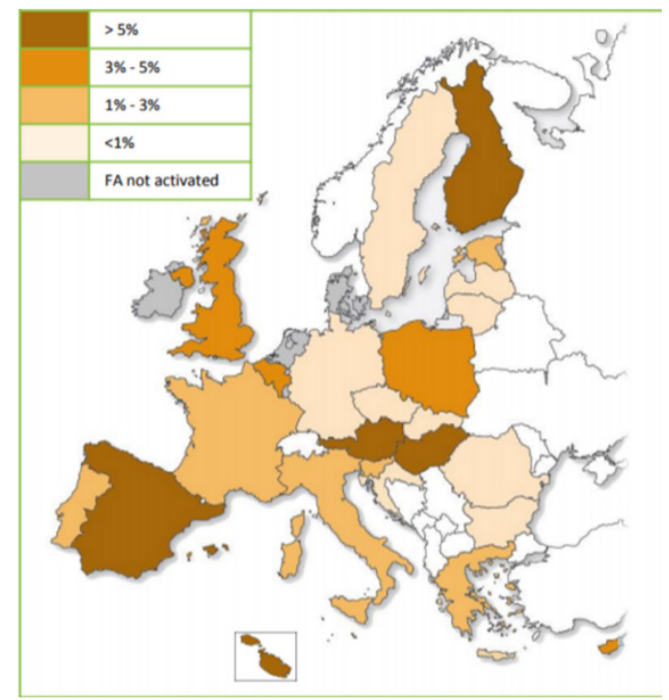

Figuur 5.1 Percentage bedrijven dat steun moet krijgen op focusgebied 3A per lidstaat

De provincie Gelderland heeft korte voorzieningsketens wel expliciet als beleidsdoel opgenomen. Maar de maatregel die ze daarvoor gebruikt gaat over samenwerken rond innovatie. De beoordeling van de projectaanvragen, de monitoring van de projectvoortgang en de evaluatie van de resultaten zijn niet gericht op het al dan niet succesvol ondersteunen van korte ketens, maar meer algemeen op horizontale of verticale samenwerking rond innovaties in bredere zin.

Er zijn ook andere provincies in Nederland die korte ketens als beleidsdoel hebben opgenomen: ZuidHolland, Noord-Brabant, Limburg, Utrecht. De ondersteuning in Gelderland is evenwel uniek vanwege het feit dat die als eis stelt dat projecten moeten worden ingediend door een gemeente in samenwerking met een streekproducent. Ze gaan er kennelijk bij de provincie van uit dat de ondersteuning van korte ketens het best gedaan kan worden op een lagere schaal dan de provincie. $\mathrm{Er}$ is ook een netwerk van gemeenten opgericht die zich met voedselbeleid bezighouden. In NoordBrabant vindt ondersteuning plaats via FoodUp, in Zuid-Holland via de Voedselfamilies. ${ }^{4}$

4 https://netwerkplatteland.nl/provincies-en-voedsel-drie-manieren-van-werken 


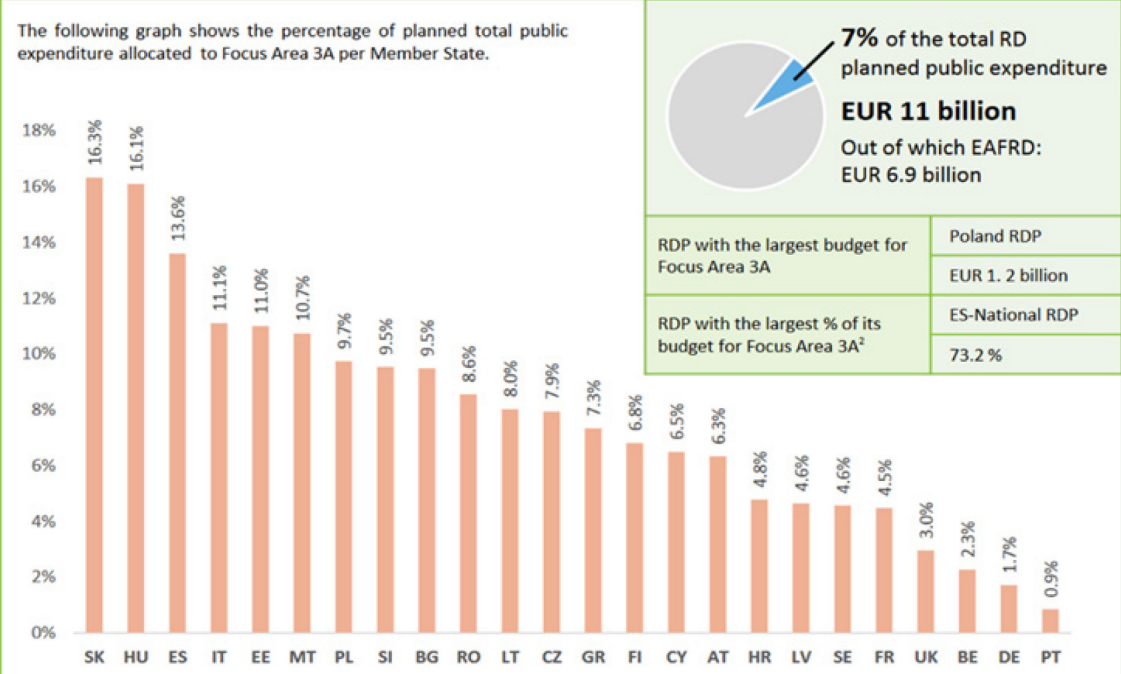

Figuur 5.2 Percentage geplande financiële middelen gericht op focusgebied 3A per lidstaat 


\section{De verdeling van korte ketens over Gelderland}

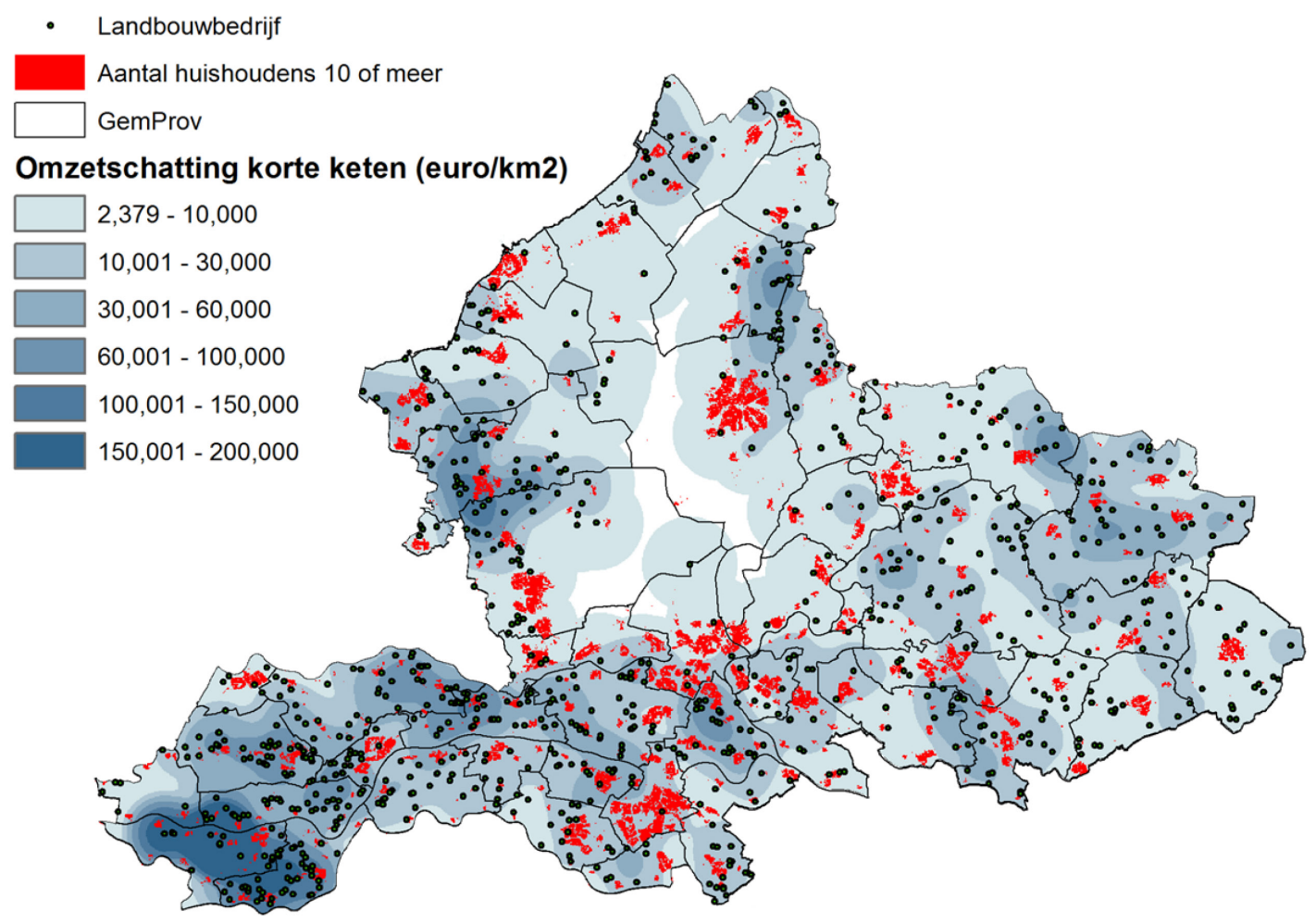

Figuur 6.1 Omzetschatting korte keten in euro's per vierkante kilometer, Landbouwtelling 2017

Figuur 6.1 laat zien hoe de verspreiding is van korte ketens in Gelderland, qua omzetschatting in euro's per vierkante kilometer. Wat valt op? Korte ketens worden vaak genoemd als ontwikkelingsrichting voor boeren die vlak bij grote steden zitten, op locaties die niet geschikt zijn om te produceren tegen lage kosten voor de wereldmarkt (Heimlich, 1989). Vlak bij grote steden is de grondprijs hoog, is het land versnipperd (doorkruising met infrastructuur, woningbouw, etc.), is arbeid duur, en er zijn vaak beperkingen omdat hinder bij omwonenden moet worden voorkomen (geen stank uit dierhouderij, geen grote landbouwmachines op de weg, etc.). Locaties vlak bij de stad hebben evenwel ook voordelen: de klanten zitten dichtbij, grondbezit vertegenwoordigt waarde die kan dienen als onderpand bij financiering en er is veel aanbod van vrijwilligers die kunnen helpen met de teelt, de oogst, het verpakken en op de markt staan.

Dit uit de literatuur bekende patroon zien we niet terug op de kaart. Arnhem-Nijmegen is een stedelijk gebied met een koopkrachtige vraag en een (hier en daar enigszins) versnipperd platteland. Toch zien we hier niet de grootste concentratie van korte ketens. Deze bevinden zich in de Bommelerwaard en de Betuwe. De vraag is waarom zich hier qua omzet per $\mathrm{km}^{2}$ de hoogste concentratie van korte ketens bevindt. Er is ook een (relatief) concentratiegebied rond Barneveld, nabij Apeldoorn (Epe) en tussen Nijmegen en Arnhem (Lingewaard).

De hoge concentratie in de Bommelerwaard zou te maken kunnen hebben met het beleid van Veiling Zaltbommel, dat expliciet gericht was op het ondersteunen van de korte keten (zie Van Rijk, 2011). ${ }^{5}$ De hoge concentraties in Rivierenland en rond Barneveld zouden te maken kunnen hebben met het karakter van de productie: fruit respectievelijk eieren behoeven geen verdere verwerking. Het product dat je oogst is het product dat je verwerkt. We komen hier later nog op terug. De relatief lagere maar in absolute zin nog steeds hoge concentraties vlak bij Apeldoorn en tussen Nijmegen en Arnhem zouden inderdaad te maken kunnen hebben met de nabijheid van de stedelijke markt.

5 https://edepot.wur.nl/159616 


\section{$7 \quad$ Het landelijke beeld met betrekking tot korte ketens}
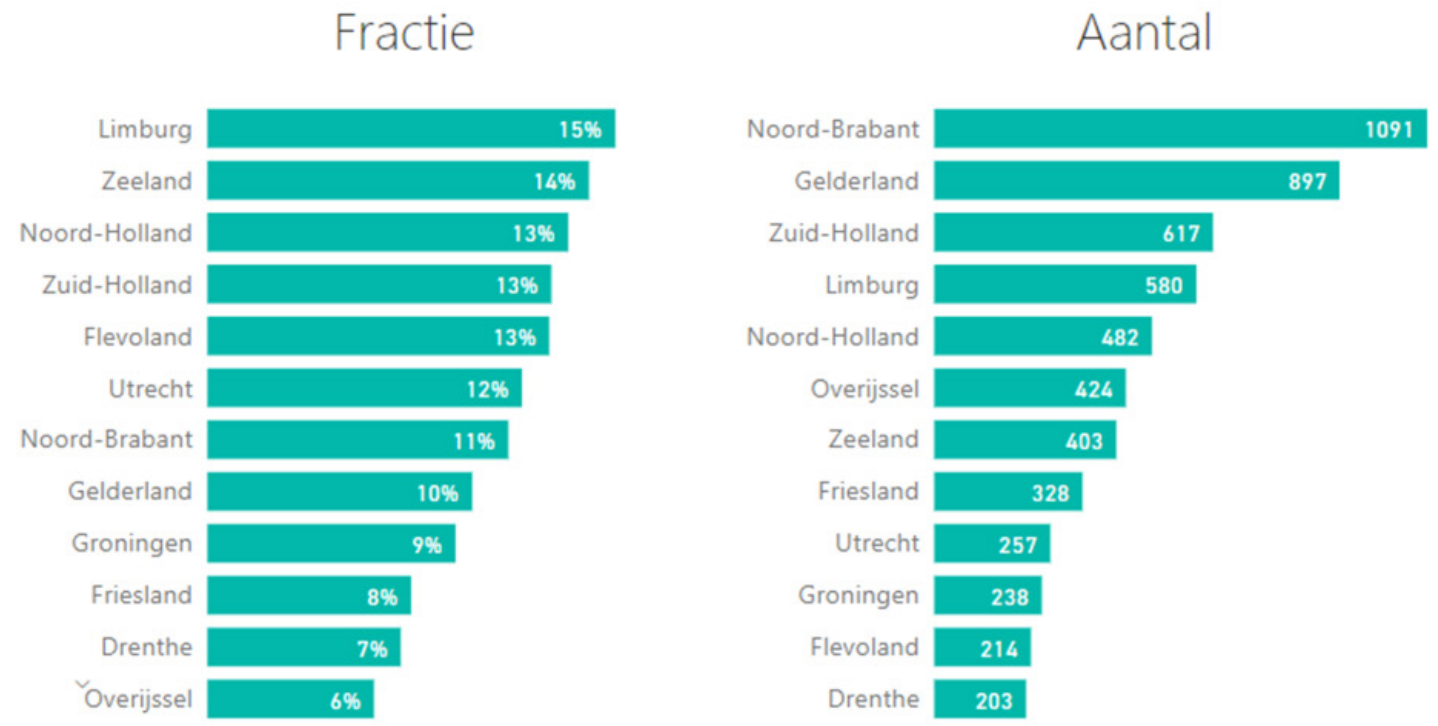

Figuur 7.1 Omvang korte ketens per provincie, in aandeel en in aantal

Figuur 7.1 geeft de omvang van korte ketens in aandelen en in aantallen. In Noord-Brabant en Gelderland zitten in absolute zin de meeste boeren die actief zijn in de korte keten, in Limburg en Zeeland zitten verhoudingsgewijs de meeste boeren in de korte keten. In Drenthe en Flevoland zitten in absolute zin de minste boeren in de korte keten, in Overijssel en Drenthe is dit aantal verhoudingsgewijs het kleinst. In Gelderland neemt $10 \%$ van de boeren deel in korte ketens (het gaat om 897 boeren). Ter vergelijking: in heel Nederland is de biologische sector $3 \%$ van het totaal aantal boeren, in Gelderland is het percentage biologische boeren 3,4\%. Het percentage boeren dat deelneemt in korte ketens is dus bijna drie keer zo hoog als het percentage boeren dat biologisch is.

De omzet van korte ketens kan niet rechtstreeks afgeleid worden uit de Landbouwtelling 2017. Daar werd gevraagd naar een inschatting als percentage van de totale omzet van het boerenbedrijf. Er kon gekozen worden uit de vier klassen: $<10 \%, 10-30 \%, 30-50 \%$ en $>50 \%$. Het midden van de klasse is overigens gebruikt om de omzet van de korte keten af te leiden van de SO (zie hierna). We hebben de totale omzet van de bedrijven geschat met behulp van de Standaard Opbrengst (SO). Dit is een schatting van de bedrijfsomzet op basis van de oppervlakten van de geteelde gewassen en de aantallen gehouden dieren per diersoort. ${ }^{6}$ In een eventueel vervolgonderzoek zouden de uitkomsten op de korteketenvraag gekoppeld kunnen worden aan de fiscale boekhouding van de bedrijven. Die geeft inzicht in de werkelijk behaalde omzet.

De berekening op basis van SO levert per provincie een schatting op van de omzet in korte ketens in absolute termen, en in relatieve termen (som geschatte opbrengst KK / som Standaard Opbrengst totaal). Uit figuur 7.2 blijkt dat de omzet in korte ketens in Noord-Brabant en Zuid-Holland het grootst is (238 miljoen respectievelijk 233 miljoen), met Gelderland als derde (129 miljoen). Relatief gezien is de opbrengst in Zeeland en Noord-Holland het hoogst (6,8\% respectievelijk 6,5\%). In Gelderland is de korteketenomzet 4,3\% van de totale omzet. Ter vergelijking: in Gelderland is de biologische landbouw $3,6 \%$ in omzet van de totale landbouw. De Gelderse biologische landbouw is daarmee ook qua omzet kleiner dan de korteketenlandbouw, hoewel dit verschil in grootte in termen van absolute aantallen veel duidelijker is (zie vorige figuur). Dit kan ermee te maken hebben dat biologische bedrijven

${ }^{6}$ https://www.wur.nl/nl/Onderzoek-Resultaten/Onderzoeksinstituten/Data-Insights-1/Bedrijfsomvang-en-type-1.htm 
volledig omschakelen, terwijl bedrijven in de korte keten vaak slechts een deel van hun omzet daarin realiseren.
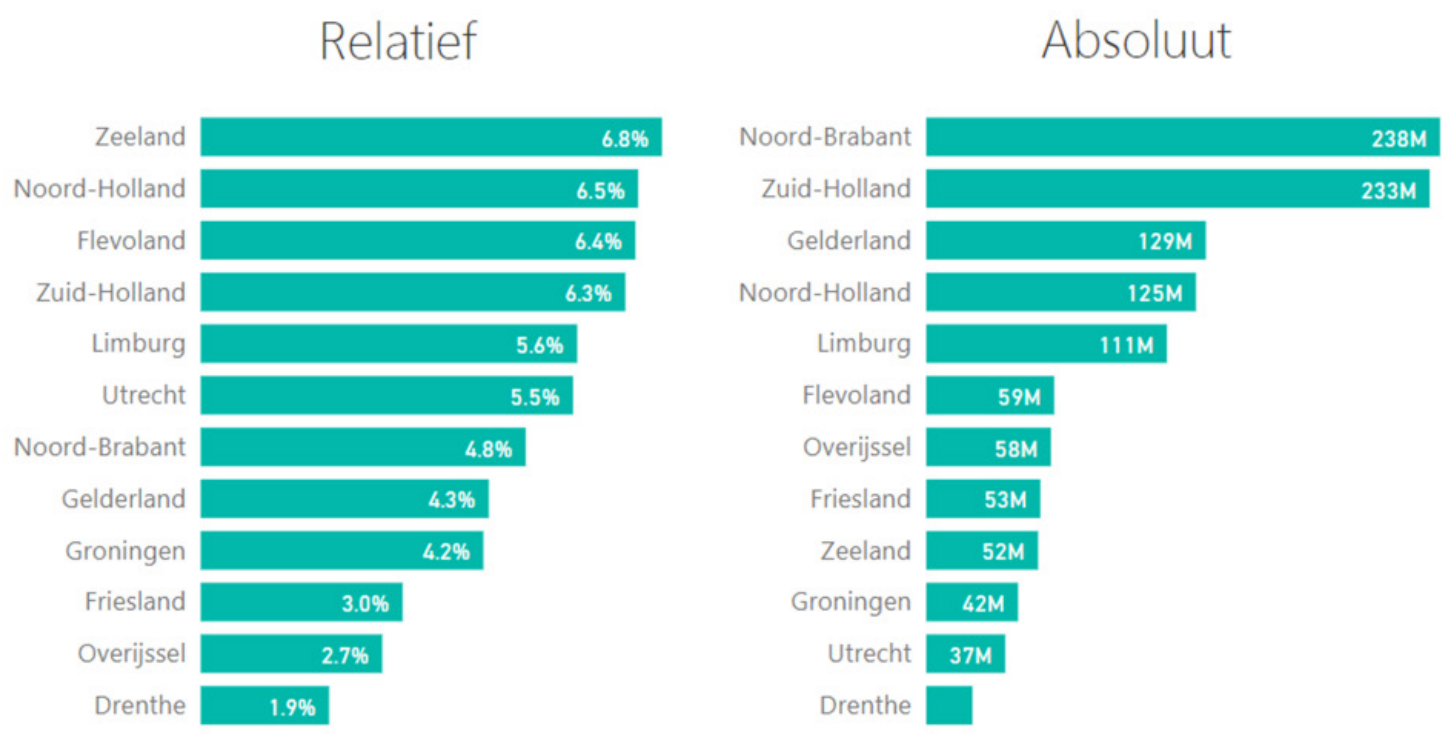

Figuur 7.2 Geschatte korteketenomzet in miljoen euro per provincie in aandeel en in omvang

Als we nog een keer kijken naar het percentage korte ketens per provincie (figuur 7.3) dan valt op dat hier geen duidelijk patroon in te ontdekken is. In de meer landelijke provincies Friesland, Drenthe en Overijssel komen korte ketens het minst vaak voor. In de meer landelijke provincies Zeeland en Limburg komen korte ketens het vaakst voor. De mate van verstedelijking speelt dus geen eenduidige rol bij het vóórkomen van korte ketens. Onderzoek naar de marktpositie van korte ketens (streekproducten) in vergelijking tot de biologische sector suggereert dat in de minder sterk verstedelijkte provincies (Limburg, Zeeland, Drenthe, Overijssel, Groningen en Friesland) inwoners zich makkelijker identificeren met producten vanuit de streek, terwijl in de Randstad mensen eerder afgaan op een keurmerk zoals biologisch (Vijn et al., 2013). Dit zou aansluiten bij de algemene karakterisering (Wiskerke, 2008) dat korte ketens ingebed zijn in sociale relaties (vertrouwen tussen boer en consument is gebaseerd op het feit dat ze elkaar persoonlijk kennen, bijvoorbeeld van het sportveld, de school of de kerk). Dit terwijl lange ketens bemiddeld worden door onpersoonlijke mechanismen (officiële kwaliteit en voedselveiligheidgarantieprogramma's, industriestandaarden, tracing en tracking). Deze gedachtegang wordt dus niet ondersteund door de gegevens uit de Landbouwtelling 2017. In sommige minder verstedelijkte provincies komen korte ketens inderdaad veel voor (Zeeland, Limburg), maar in andere juist niet (Friesland, Drenthe en Overijssel). Ook valt op dat in Noord-Holland en Zuid-Holland het percentage korte ketens relatief hoog is, terwijl Vijn et al. (2013; evenals Wiskerke, 2008) suggereren dat keurmerken hier een belangrijkere rol zouden spelen. Klaarblijkelijk zijn er ook andere factoren van belang om te verklaren waarom korte ketens meer of minder voorkomen. 


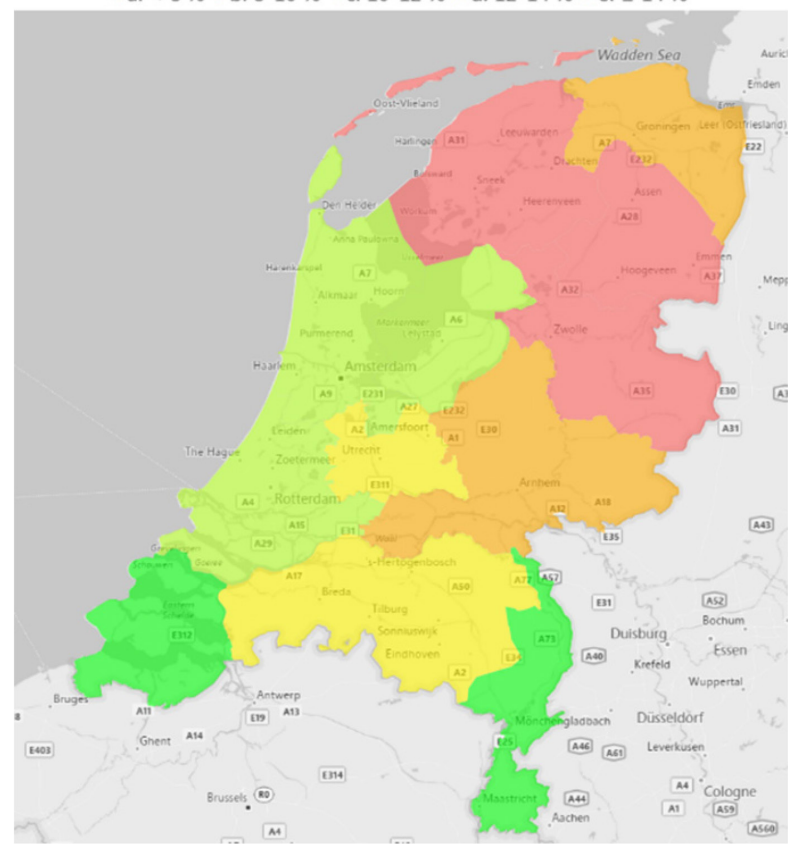

Figuur 7.3 Aandeel bedrijven met korte ketens per provincie 


\section{Een sectoraal beeld van korte ketens}
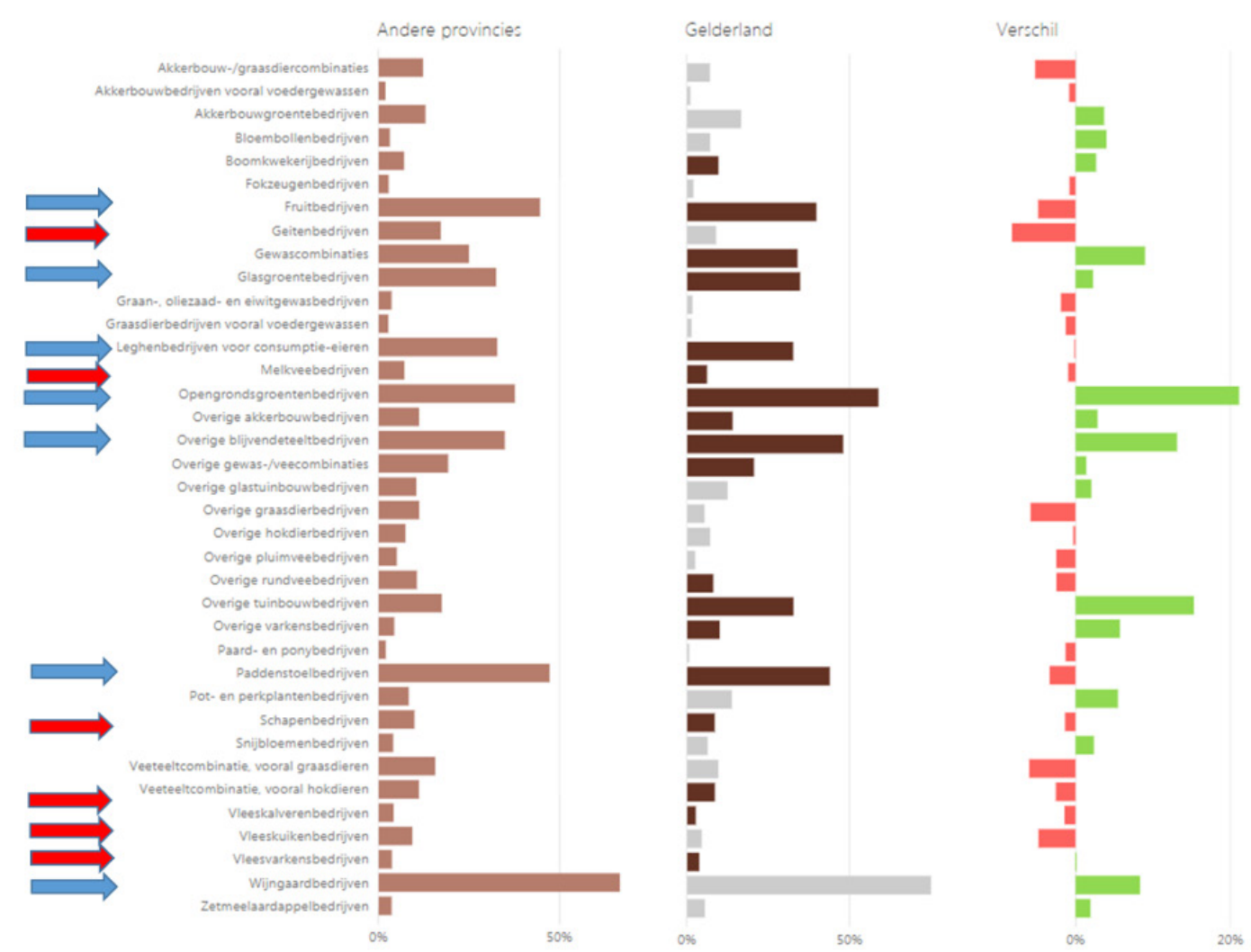

Figuur 8.1 Percentage bedrijven met korte keten per sector a) a) Grijze staven betekenen minder dan tien observaties

Als we kijken naar het percentage korte ketens per sector (figuur 8.1), dan valt op dat dit percentage het hoogst is voor die sectoren waarbij er geen of slechts lichte bewerkingen hoeven plaats te vinden voordat het product aan de eindconsument verkocht kan worden. Dit gaat op voor fruitbedrijven, glasgroentebedrijven, leghenbedrijven voor consumptie-eieren, opengrondsgroentebedrijven, overige blijvende teelt bedrijven, ${ }^{7}$ en paddenstoelenbedrijven. Het fruit dat je als producent plukt is het fruit dat je als consument koopt, het ei dat je als producent raapt is het ei dat je als consument koopt. Er zijn geen of nauwelijks bewerkingsslagen nodig. Boeren hoeven dus nauwelijks te investeren in verwerkingscapaciteit en kunnen vrij makkelijk instappen in de korteketeneconomie. Op deze manier valt ook te verklaren waarom geitenbedrijven, melkveebedrijven, schapenbedrijven,

vleeskalverenbedrijven, vleeskuikenbedrijven en vleesvarkensbedrijven relatief weinig in korte ketens deelnemen. Voor deze sectoren zijn bewerkingsstappen immers essentieel voordat het product aan eindconsumenten verkocht kan worden (slachten, uitsnijden, verzuivelen, verpakken, etc.). Een voorbeeld uit de Masterclass Produceren in de Korte Keten Ede Barneveld is vleeskuikenhouder Erik van Veldhuisen uit Renswoude, die van zijn slachterij geen garantie kon krijgen dat dezelfde kippen die hij daar liet slachten ook daadwerkelijk weer aan hem terug geleverd zouden worden, voor eigen verkoop via de korte keten. ${ }^{8}$ Erik moest uitwijken naar een andere slachterij, en hij is niet de enige die hier tegenaan loopt. Melk- en vleesveehouder Roel van Dijk, ook deelnemer van de Masterclass Produceren in de Korte Keten Ede Barneveld, laat van een deel van zijn melk kaas maken. De zuivelfabriek wilde dat hij voortaan ál zijn melk aan hen zou verkopen. Van Dijk weigerde dit, en het

\footnotetext{
7 Dat zijn vooral bedrijven die ofwel een mix hebben van fruit opengrond, wijngaard, fruit onder glas of noten, of waar het zwaartepunt van de productie zit bij fruit onder glas of noten.

8 https://www. nieuweoogst. nu/nieuws/2019/01/14/pluimveehouder-verkoopt-zelf-kippenvlees
} 
contract met de zuivelfabriek moest worden ontbonden. ${ }^{9}$ Hieruit blijkt dat verwerkende schakels er moeite mee hebben hun contract met toeleverende boeren zo te organiseren dat deze zelf de controle behouden over hun afzetketen.

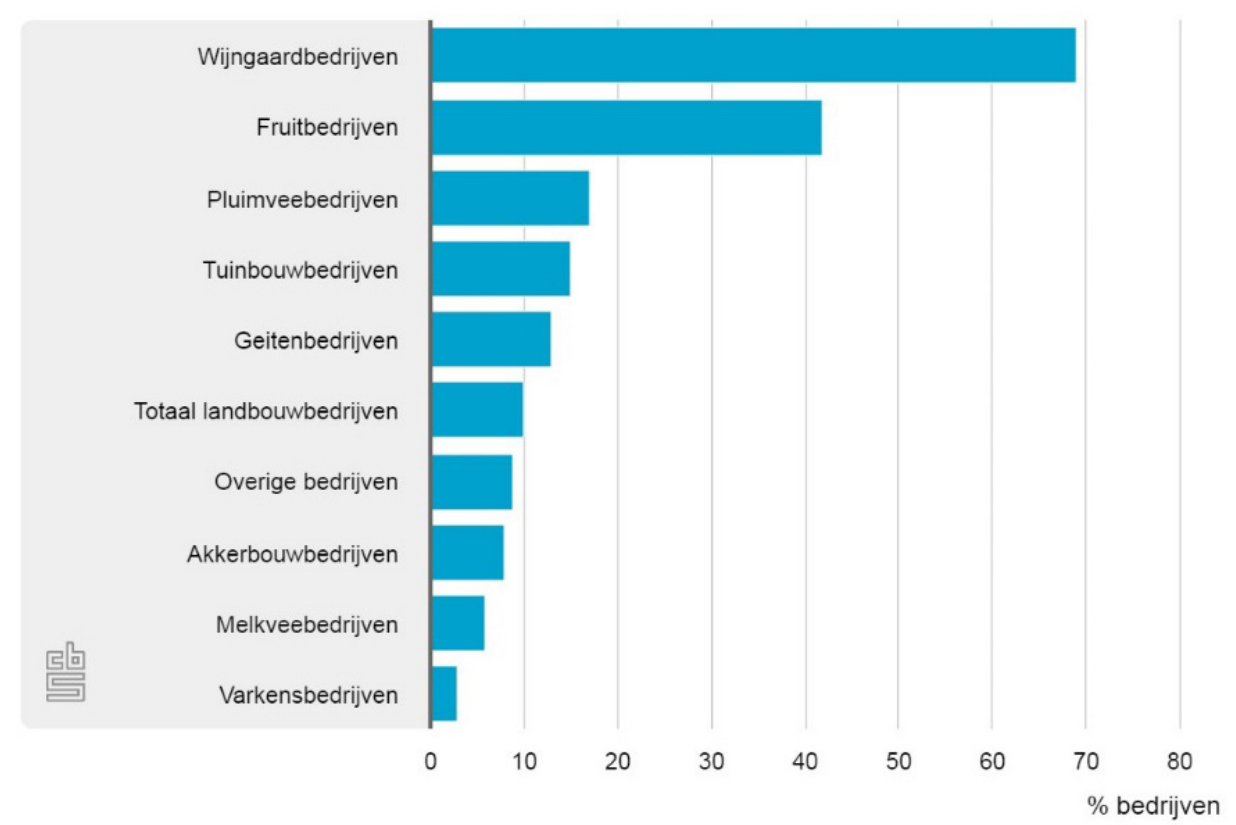

Figuur 8.2 Aantal bedrijven met korte ketens per sector Bron: $C B S$.

Het CBS komt ook met een opsomming van sectoren waar korte ketens veel of juist weinig voorkomen. ${ }^{10}$ Maar ze kiezen voor een hoger aggregatieniveau (pluimveebedrijven zijn zowel leghenbedrijven voor eierproductie als vleeskuikenbedrijven). Om deze reden komt het beeld qua onderliggende verklaring (noodzaak tot be- of verwerking) ook minder duidelijk naar voren (zie figuur 8.2). Ze constateren terecht dat de wijngaardbedrijven in Nederland het hoogste percentage afzet in korte ketens leveren. Maar wijnboeren zijn in de korteketeneconomie eerder een uitzondering dan de norm, omdat in hun voorzieningsketen een vorm van bewerking nodig is (van druiven naar wijn) die zij weten te organiseren (collectief of individueel), terwijl andere sectoren daar minder toe in staat blijken.

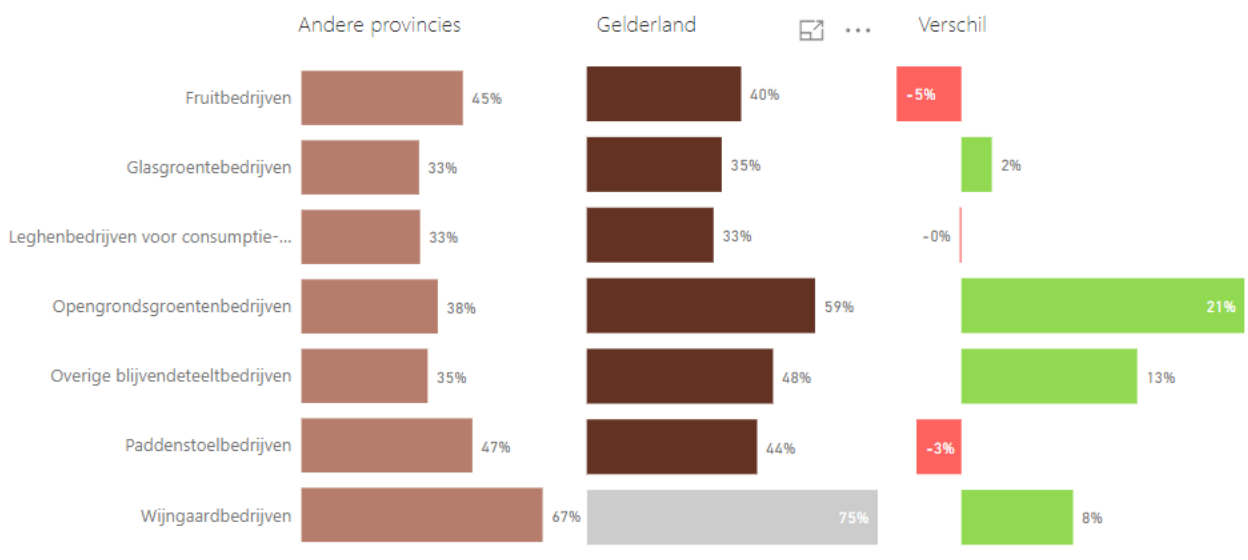

Figuur 8.3 Aandeel korte keten bedrijven per sector in Gelderland ten opzichte van de rest van Nederland

\footnotetext{
9 https://www.omroepgelderland.nl/nieuws/2409139/Boeren-willen-met-streekproducten-de-boer-op

10 https://www.cbs.nl/nl-nl/nieuws/2018/51/wijnboeren-leveren-vaakst-direct-aan-consument
} 
Uit figuur 8.3 blijkt ook dat Gelderland in een aantal sectoren vooroploopt qua korte ketens ten opzichte van de overige provincies: opengrondsgroentebedrijven, overige blijvende teeltbedrijven en overige tuinbouwbedrijven. ${ }^{11}$ In een aantal sectoren loopt Gelderland iets achter: met name de geitenbedrijven.

${ }^{11}$ Dit zijn bedrijven die vooral aan tuinbouw doen en niet zijn opgenomen in de 'gespecialiseerde bedrijfstypen', zoals glasgroenten, glasbloemen, bollen, paddenstoelen en dergelijk. In de praktijk gaat het vaak om bedrijven met meerdere tuinbouwactiviteiten (zoals bloembollen plus bollenbroei of glasgroenten plus opengrondsgroenten). 


\section{Geografische spreiding van korte ketens in Gelderland}
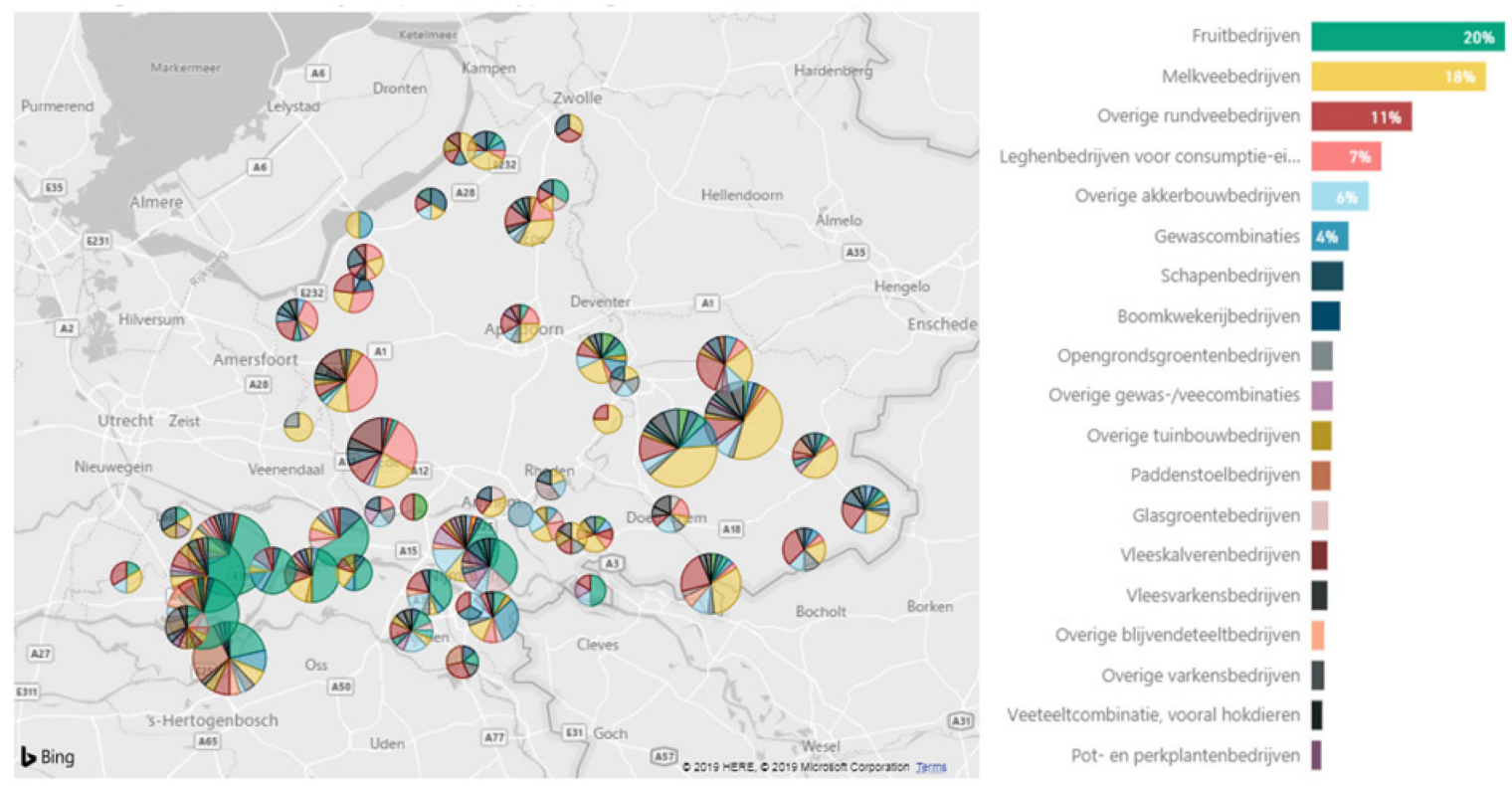

Figuur 9.1 Verdeling korteketenbedrijven per sector en per gemeente

Een discussie over de rol van regionale voedselsystemen begint vaak met de vraag of een bepaalde stadsregio zichzelf zou kunnen voeden gegeven de voedselproductie in het ommeland. Voor Arnhem is al eerder gekeken of deze stad zich zou kunnen voeden met louter producten uit de omliggende stadsregio Arnhem-Nijmegen (Van der Schans en Klein Gebbink, 2014). Uit onderzoek blijkt dat Arnhem-Nijmegen gegeven het huidig landgebruik en de huidige consumptiepatronen zelfvoorzienend kan zijn voor consumptieaardappelen, groenten, appels en peren, maar niet voor granen. Daarbij moet worden aangetekend dat de granen die in de regio geteeld worden momenteel vooral als veevoer dienen, terwijl de granen die gebruikt worden voor menselijke consumptie niet lokaal geteeld worden. Ook voor diverse groepen veehouderijproducten is gekeken of productie en consumptie op regioniveau in balans zijn. Dit blijkt niet het geval te zijn. Voor alle vleescategorieën (varkens, rund en pluimvee) is de consumptie (veel) hoger dan de productie. Voor zuivel en voor eieren is de regio meer dan zelfvoorzienend. Daarbij moeten we ook hier weer in ogenschouw nemen dat het in de regio geproduceerde rundvlees waarschijnlijk niet de kwaliteit heeft die de consument vraagt, omdat het bijvoorbeeld van oude melkkoeien komt terwijl er juist vraag is naar vlees van speciaal voor dit doel gefokt en gehouden vleesvee.

In onderhavig onderzoek is niet gekeken of er in Gelderland theoretisch genoeg ruimte zou zijn om voor de huidige inwoners het huidige consumptiepatroon in te vullen. Wel is gekeken in hoeverre Gelderse gemeenten nu al praktisch in staat zijn een gevarieerd menu te bieden via de korte keten. Of is er sprake van specialisatie per regio, waardoor op die plaatsen het korteketenmenu slechts eenzijdig ingevuld kan worden? Figuur 9.1 geeft aan wat de verdeling van korteketenbedrijven is over sectoren per gemeente. Je kunt op deze manier goed zien dat bepaalde regio's in Gelderland qua korte ketens gedomineerd worden door één of enkele sectoren, zoals de fruitteelt in de Betuwe, de melkveehouderij in de Achterhoek en de eierenproductie in de buurt van Barneveld. Het is dus voor consumenten dan een uitdaging om in deze regio's een volledig menu via de korte keten te betrekken. Deze uitdaging kan opgelost worden door de range aan sectoren binnen de regio te verbreden. Maar ook kan de consument het gebied waarbinnen hij zoekt vergroten, net zo lang tot hij een breed scala van menucomponenten via korte ketens aangeboden krijgt. Interessant is dat rond de steden Nijmegen en Arnhem het scala aan sectoren die in korte ketens actief zijn tamelijk gevarieerd is. Het 
moet dus mogelijk zijn in deze stadsregio nu al een rijk gevarieerd aanbod van korteketenproducten samen te stellen. ${ }^{12}$
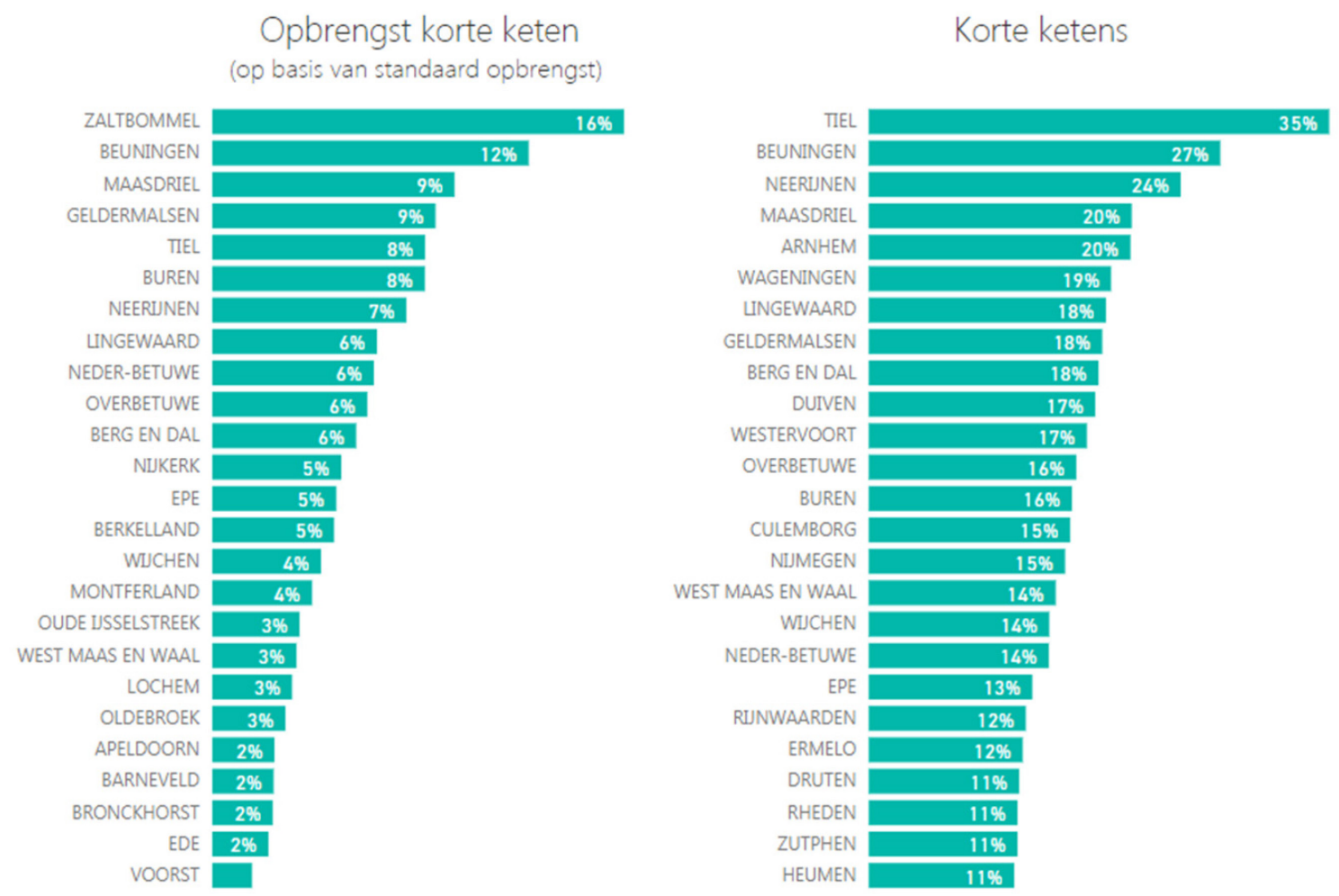

Figuur 9.2 Aandeel korteketenbedrijven in totaal aantal bedrijven en geschatte opbrengst korteketenbedrijven in totale opbrengst per gemeente

In de gemeente Tiel neemt maar liefst 35\% van de boeren deel aan een korte keten, het gaat om $8 \%$ van de geschatte opbrengst. In Tiel gaat het dus vooral om wat meer kleinschalige initiatieven. In de gemeente Zaltbommel vindt maar liefst $16 \%$ van de totale omzet plaats in de korte keten. Deze gemeente staat daarmee op de eerste plaats in Gelderland. Qua aantal ondernemers staat Zaltbommel op de 31e plaats. Het gaat in Zaltbommel dus om relatief grote bedrijven. Dit is de tabel op basis waarvan het kaartje in figuur 6.1 gemaakt is, zie voor een interpretatie aldaar.

\footnotetext{
${ }^{12}$ Dit is dus een andere insteek dan een theoretisch scenario waarbij alle inwoners van die stadsregio volledig gevoed zouden kunnen worden, zoals Van der Schans en Klein Gebbink hebben onderzocht in 2014.
} 


\begin{tabular}{|c|c|c|c|c|c|c|c|c|c|c|c|c|c|c|}
\hline \multicolumn{5}{|c|}{ 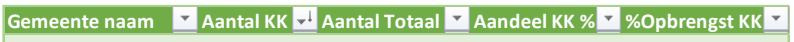 } & \multicolumn{5}{|c|}{ 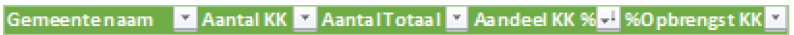 } & \multicolumn{5}{|c|}{ 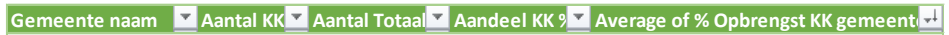 } \\
\hline BUREN & 50 & 322 & $15.5 \%$ & $8.1 \%$ & TIEL & 19 & 54 & $35.2 \%$ & $8.1 \%$ & ZALTBOMMEL & 16 & 180 & $8,9 \%$ & $15,7 \%$ \\
\hline BERKELLAND & 46 & 696 & $6.6 \%$ & $4.7 \%$ & BEUNINGEN & 18 & 67 & $26.9 \%$ & $12.1 \%$ & BEUNINGEN & 18 & 67 & $26,9 \%$ & $12,1 \%$ \\
\hline BRONCKHORST & 46 & 615 & $7.5 \%$ & $2.3 \%$ & NEERIJNEN & 41 & 172 & $23.8 \%$ & $7.4 \%$ & MAASDRIEL & 42 & 209 & $20,1 \%$ & $9,3 \%$ \\
\hline GELDERMALSEN & 43 & 241 & $17.8 \%$ & $8.5 \%$ & MAASDRIEL & 42 & 209 & 20.196 & $9.3 \%$ & GELDERMALSEN & 43 & 241 & $17,8 \%$ & $8,5 \%$ \\
\hline MAASDRIEL & 42 & 209 & $20.1 \%$ & $9.3 \%$ & LINGEWAARD & 27 & 149 & $18.1 \%$ & $6.3 \%$ & TIEL & 19 & 54 & $35,2 \%$ & $8,1 \%$ \\
\hline NEERIJNEN & 41 & 172 & $23.8 \%$ & $7.4 \%$ & GELDERMALSEN & 43 & 241 & $17.8 \%$ & $8.5 \%$ & BUREN & 50 & 322 & $15,5 \%$ & $8,1 \%$ \\
\hline EDE & 39 & 701 & $5.6 \%$ & $2.2 \%$ & BERG EN DAL & 23 & 131 & $17.6 \%$ & $5.5 \%$ & NEERINEN & 41 & 172 & $23,8 \%$ & $7,4 \%$ \\
\hline OVERBETUWE & 36 & 227 & $15.9 \%$ & $5.9 \%$ & OVERBETUWE & 36 & 227 & $15.9 \%$ & $5.9 \%$ & LINGEWAARD & 27 & 149 & $18,1 \%$ & $6,3 \%$ \\
\hline BARNEVELD & 33 & 550 & $6.0 \%$ & $2.4 \%$ & BUREN & 50 & 322 & $15.5 \%$ & $8.1 \%$ & NEDER-BETUWE & 30 & 218 & $13,8 \%$ & $6,2 \%$ \\
\hline OUDE IJSSELSTREEK & 31 & 324 & $9.6 \%$ & $3.3 \%$ & WEST MAAS EN WAAL & 26 & 182 & $14.3 \%$ & $3.2 \%$ & OVERBETUWE & 36 & 227 & $15,9 \%$ & $5,9 \%$ \\
\hline NEDER-BETUWE & 30 & 218 & $13.8 \%$ & $6.2 \%$ & WIJCHEN & 16 & 116 & $13.8 \%$ & $4.2 \%$ & BERG EN DAL & 23 & 131 & $17,6 \%$ & $5,5 \%$ \\
\hline LINGEWAARD & 27 & 149 & $18.1 \%$ & $6.3 \%$ & NEDER-BETUWE & 30 & 218 & $13.8 \%$ & $6.2 \%$ & NIJKERK & 15 & 165 & $9,1 \%$ & $4,9 \%$ \\
\hline LOCHEM & 27 & 402 & $6.7 \%$ & $3.1 \%$ & EPE & 21 & 168 & $12.5 \%$ & $4.7 \%$ & EPE & 21 & 168 & $12,5 \%$ & $4,7 \%$ \\
\hline WEST MAAS EN WAAL & 26 & 182 & $14.3 \%$ & $3.2 \%$ & ERMELOO & 10 & 85 & 11.866 & 2.796 & BERKELLAND & 46 & 696 & $6,6 \%$ & $4,7 \%$ \\
\hline BERG EN DAL & 23 & 131 & $17.6 \%$ & $5.5 \%$ & DRUTEN & 10 & 87 & $11.5 \%$ & $2.3 \%$ & WIJCHEN & 16 & 116 & $13,8 \%$ & $4,2 \%$ \\
\hline VOORST & 22 & 253 & $8.7 \%$ & $1.5 \%$ & OUDE ISSSELST REEK & 31 & 324 & $9.6 \%$ & $3.3 \%$ & MONTFERLAND & 10 & 210 & $4,8 \%$ & $3,8 \%$ \\
\hline EPE & 21 & 168 & $12.5 \%$ & $4.7 \%$ & NIJKERK & 15 & 165 & $9.1 \%$ & $4.9 \%$ & OUDE IJSSELSTREEK & 31 & 324 & $9,6 \%$ & $3,3 \%$ \\
\hline WINTERSWIJK & 20 & 274 & $7.3 \%$ & $1.3 \%$ & ZALTBOMMEL & 16 & 180 & $8.9 \%$ & $15.7 \%$ & WEST MAAS EN WAAL & 26 & 182 & $14,3 \%$ & $3,2 \%$ \\
\hline TIEL & 19 & 54 & $35.2 \%$ & $8.1 \%$ & VOORST & 22 & 253 & $8.7 \%$ & $1.5 \%$ & LOCHEM & 27 & 402 & $6,7 \%$ & $3,1 \%$ \\
\hline BEUNINGEN & 18 & 67 & $26.9 \%$ & $12.1 \%$ & BRONCKHORST & 46 & 615 & $7.5 \%$ & $2.3 \%$ & OLDEBROEK & 12 & 170 & $7,1 \%$ & $2,8 \%$ \\
\hline OOST GELRE & 18 & 307 & $5.9 \%$ & $1.2 \%$ & WINTERSWIJK & 20 & 274 & $7.3 \%$ & $1.3 \%$ & ERMELO & 10 & 85 & $11,8 \%$ & $2,7 \%$ \\
\hline ZALTBOMMEL & 16 & 180 & $8.9 \%$ & $15.7 \%$ & OLDEBROEK & 12 & 170 & 7.196 & 2.896 & APELDOORN & 12 & 200 & $6,0 \%$ & $2,4 \%$ \\
\hline WIJCHEN & 16 & 116 & $13.8 \%$ & $4.2 \%$ & LOCHEM & 27 & 402 & $6.7 \%$ & $3.1 \%$ & BARNEVELD & 33 & 550 & $6,0 \%$ & $2,4 \%$ \\
\hline AALTEN & 16 & 270 & $5.9 \%$ & $1.4 \%$ & BERKELLAND & 46 & 696 & $6.6 \%$ & $4.7 \%$ & BRONCKHORST & 46 & 615 & $7,5 \%$ & $2,3 \%$ \\
\hline NIJKERK & 15 & 165 & $9.1 \%$ & $4.9 \%$ & DOETINCHEM & 11 & 174 & $6.3 \%$ & $2.0 \% 6$ & DRUTEN & 10 & 87 & $11,5 \%$ & $2,3 \%$ \\
\hline PUTTEN & 13 & 222 & $5.9 \%$ & $0.8 \%$ & APELDOORN & 12 & 200 & $6.0 \%$ & $2.4 \%$ & EDE & 39 & 701 & $5,6 \%$ & $2,2 \%$ \\
\hline OLDEBROEK & 12 & 170 & $7.1 \%$ & $2.8 \%$ & BARNEVELD & 33 & 550 & $6.0 \% 6$ & $2.4 \%$ & DOETINCHEM & 11 & 174 & $6,3 \%$ & $2,0 \%$ \\
\hline APELDOORN & 12 & 200 & $6.0 \%$ & $2.4 \%$ & AALTEN & 16 & 270 & $5.9 \%$ & $1.4 \%$ & VOORST & 22 & 253 & $8,7 \%$ & 1,5\% \\
\hline DOETINCHEM & 11 & 174 & $6.3 \%$ & $2.0 \%$ & OOST GELRE & 18 & 307 & $5.9 \%$ & $1.2 \%$ & AALTEN & 16 & 270 & $5,9 \%$ & $1,4 \%$ \\
\hline MONTFERLAND & 10 & 210 & $4.8 \%$ & $3.8 \%$ & PUTTEN & 13 & 222 & $5.9 \%$ & $0.8 \%$ & WINTERSWIJK & 20 & 274 & $7,3 \%$ & $1,3 \%$ \\
\hline ERMELO & 10 & 85 & $11.8 \%$ & $2.7 \%$ & EDE & 39 & 701 & $5.6 \%$ & $2.2 \%$ & OOST GELRE & 18 & 307 & $5,9 \%$ & $1,2 \%$ \\
\hline DRUTEN & 10 & 87 & $11.5 \%$ & $2.3 \%$ & MONTFERLAND & 10 & 210 & $4.8 \%$ & $3.8 \%$ & PUTTEN & 13 & 222 & $5,9 \%$ & $0,8 \%$ \\
\hline NIJMEGEN & & 20 & & & NUNSPEET & & 104 & & & NIJMEGEN & & 20 & & \\
\hline RENKUM & 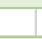 & 19 & & & ELBURG & & 99 & & & RENKUM & & 19 & & \\
\hline ARNHEM & & 25 & & & BRUMMEN & & 98 & & & ARNHEM & & 25 & & \\
\hline DUIVEN & & 52 & & & LINGEWAAL & & 85 & & & DUIVEN & & 52 & & \\
\hline ELBURG & & 99 & & & ZEVENAAR & & 83 & & & ELBURG & & 99 & & \\
\hline HEUMEN & 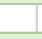 & 63 & & & HEERDE & & 75 & & & HEUMEN & & 63 & & \\
\hline RIJNWAARDEN & & 50 & & & HEUMEN & & 63 & & & RIJNWAARDEN & & 50 & & \\
\hline CULEMBORG & & 39 & & & DUIVEN & & 52 & & & CULEMBORG & & 39 & & \\
\hline WAGENINGEN & & 27 & & & RIJNWAARDEN & & 50 & & & WAGENINGEN & & 27 & & \\
\hline WESTERVOORT & 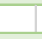 & 6 & & & RHEDEN & & 44 & & & WESTERVOORT & & 6 & & \\
\hline ZEVENAAR & & 83 & & & ZUTPHEN & & 44 & & & ZEVENAAR & & 83 & & \\
\hline BRUMMEN & 7 & 98 & & & CULEMBORG & & 39 & & & BRUMMEN & & 98 & & \\
\hline LINGEWAAL & & 85 & & & SCHERPENZEEL & & 38 & & & LINGEWAAL & & 85 & & \\
\hline NUNSPEET & 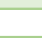 & 104 & & & HATTEM & & 30 & & & NUNSPEET & & 104 & & \\
\hline RHEDEN & & 44 & & & HARDERWJJK & & 28 & & & RHEDEN & & 44 & & \\
\hline HEERDE & 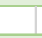 & 75 & & & WAGENINGEN & & 27 & & & HEERDE & & 75 & & \\
\hline HATTEM & & 30 & & & ARNHEM & & 25 & & & HATTEM & & 30 & & \\
\hline ZUTPHEN & 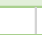 & 44 & & & NIJMEGEN & & 20 & & & ZUTPHEN & & 44 & & \\
\hline SCHERPENZEEL & & 38 & & & RENKUM & & 19 & & & SCHERPENZEEL & & 38 & & \\
\hline HARDERWIJK & . & 28 & & & DOESBURG & & 13 & & & HARDERWIJK & & 28 & & \\
\hline DOESBURG & & 13 & & & WESTERVOORT & & 6 & & & DOESBURG & & 13 & & \\
\hline
\end{tabular}

Figuur 9.3 Ranking van gemeenten naar aantal korteketenbedrijven, aandeel in het totaal aantal bedrijven, en (geschatte) omzet 
Figuur 9.3 gaat om een ranking qua aantallen korteketenbedrijven, qua aandeel in het totaal aantal bedrijven, en qua omzet: het gemiddeld aandeel korteketenopbrengst (schatting). Het gaat om de gemiddelde omzetten per gemeente, niet per individuele boer.

De gemeente Buren heeft de meeste boeren die opereren in korte ketens (50), gevolgd door Berkelland (46) en Bronckhorst (46). In de gemeente Tiel is het aandeel boeren in korte ketens ten opzichte van het totaal aantal boeren het grootst (35\%), gevolgd door Beuningen (27\%) en Neerijnen (24\%). In de gemeente Zaltbommel is het gemiddeld aandeel korteketenopbrengst in de totale opbrengst het hoogst (16\%), gevolgd door Beuningen (22\%) en Maasdriel. Vakken met minder dan tien waarnemingen worden om privacy-redenen niet gepubliceerd. 


\section{Korte ketens en bedrijfstructuur}

Opbrengst korte keten a. $<2 \%$ b. $2-4 \%$ c. $4-6 \%$ d. $6-10 \%$ e. $\geq 10 \%$

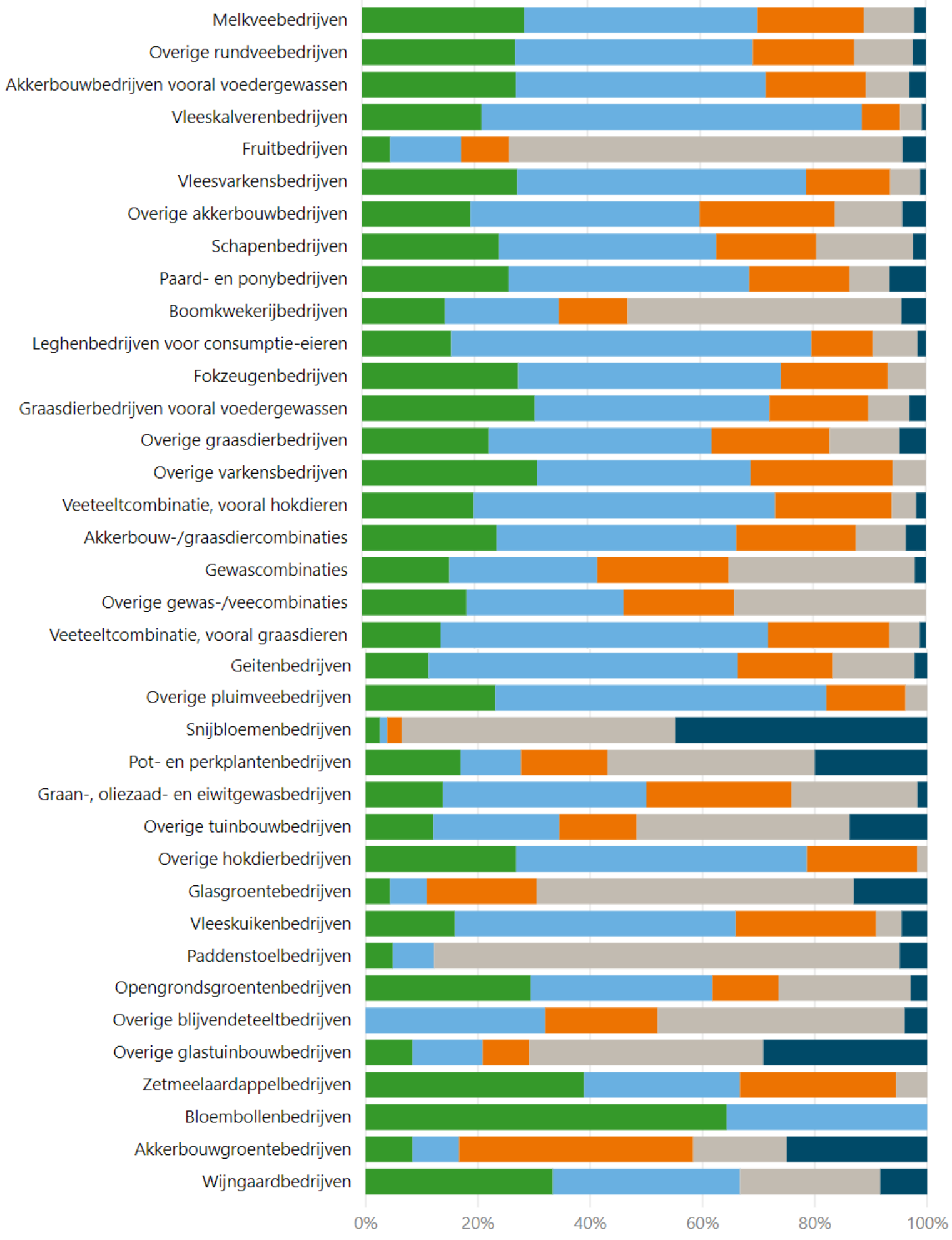

Figuur 10.1 Omzet aandelen uit de korte keten per sector in Gelderland 
In Gelderland zijn een beperkt aantal sectoren waarin veel bedrijven een relatief grote omzet in de korte keten hebben: het gaat met name om snijbloemen, pot- en perkplanten, overige glastuinbouwbedrijven en akkerbouwgroentebedrijven. Dit zijn allemaal sectoren waar geen of slechts een lichte bewerking nodig is. Er zijn relatief veel sectoren met een zeer klein aandeel van hun omzet in de korte keten. Hier zitten ook sectoren bij met producten die een bewerkingsslag vragen (melkveebedrijven, graasdierbedrijven, overige varkensbedrijven, zetmeelaardappelenbedrijven, en wijngaardbedrijven). Dit zijn waarschijnlijk bedrijven die (naast het hoofdproduct voor de lange keten) heel kleine hoeveelheden onbewerkte producten van het erf of uit de tuin of boomgaard verkopen (scharrelkippen, fruit of noten van erfbeplanting, etc.). Het gaat anders gezegd om bedrijven die de verwerking van kleine hoeveelheden elders laten plaatsvinden en het eindproduct dan weer wel zelf verkopen. Een voorbeeld van dit laatste is Boerderijwinkel De Pippert van de familie Kranendonk. ${ }^{13} \mathrm{Zij}$ verkopen in hun campingwinkel kleine hoeveelheden kaas van eigen melk die ze evenwel elders laten maken. Het beeld ontstaat dat veel bedrijven al iets doen met korte ketens. Dit laat een zekere belangstelling en potentie zien. Maar veel minder bedrijven pakken nu al door en specialiseren zich echt in de korte keten.

Uit de data van de Meitelling 2017 blijkt (figuur 10.2) dat zeer grote bedrijven (14\%) in Nederland relatief meer aan korte ketens deelnemen dan zeer kleine bedrijven (9\%). (Grootteklasse gebaseerd op standaard verdiencapaciteit zeer klein: <25.000, klein: 25.000-60.000, gemiddeld: 60.000-

100.000, groot: 100.000-250.000, zeer groot: >250.000.) Dit is een opmerkelijke uitkomst, want er wordt regelmatig gesteld dat korte ketens vooral een alternatief zijn voor boeren die te klein zijn om de concurrentie op de wereldmarkt aan te kunnen. Dit is de conclusie die Galli en Brunori trekken in een overzicht van korteketenonderzoek in het FP7-programma van de EU:

'It is characteristic that especially small and medium farmers are involved in SFSCs. This stems from the fact that they are often less competitive in the conventional chains due to their higher costs of production (because of the lack of economies of scale and the different organisation of production processes) and the higher prices. In many cases these farms do not have easy access to the conventional channels also because of the inconsistency in their supply, in terms of volume, quality and/or continuity. Providing a fair access to the market, SFSCs represent a solution to increase economic viability of small and medium farms and processing companies' (Galli and Brunori, 2013).
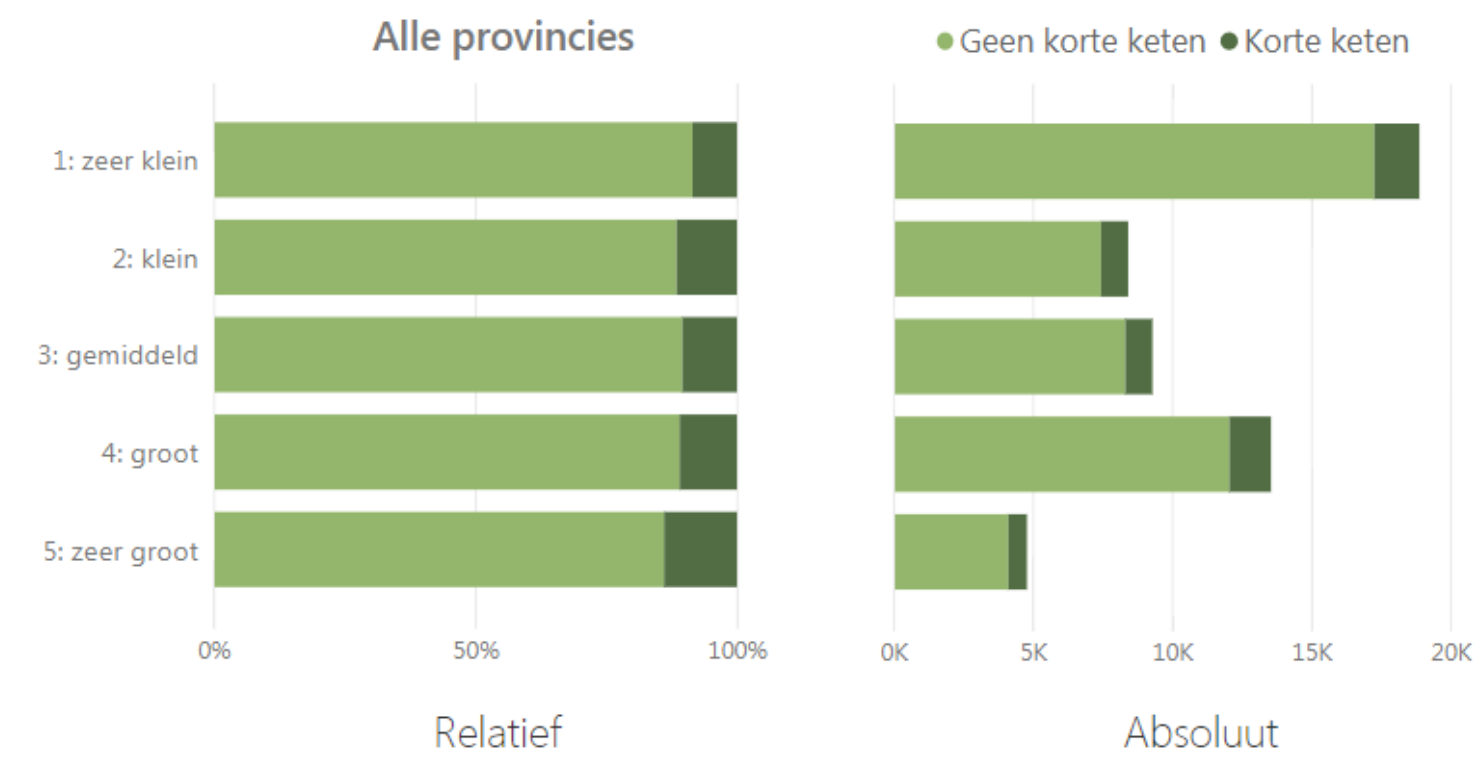

Figuur 10.2 Aandeel korteketenbedrijven per grootteklasse

13 http://www.depippert.nl 
Hoewel zeer grote bedrijven relatief vaker in korte ketens opereren doe je er echter goed aan ook naar zeer kleine bedrijven te kijken, als je een korte keten wilt vinden in Nederland. Er zijn namelijk absoluut gezien veel meer kleine bedrijven in Nederland. Er zijn dus ook meer kleine korteketenbedrijven, dan zeer grote korteketenbedrijven.

Een voorbeeld van een zeer groot bedrijf dat in korte ketens actief is: Novifarm, ${ }^{14}$ een akkerbouwbedrijf in Zuid-Holland met 771 ha en een bouwplan voornamelijk gericht op de wereldmarkt (tarwe, luzerne, suikerbieten, knolselderij, uien en aardappelen). Dit bedrijf heeft evenwel sinds 2015 een samenwerking met Bram Ladage, een regionale frietbakker, waaraan het rechtstreeks of via één tussenschakel in de schil gewassen aardappelen levert. Ladage gebruikt deze aardappelen uit de korte keten als ingrediënt voor een nieuw fast food-concept: Bram's Gourmet Frites. ${ }^{15}$ Het gaat in 2016 om 10 ha (van de 160 ha aardappelen in het bouwplan van Novifarm). Een ander voorbeeld van een zeer groot bedrijf dat in korte ketens actief is: Kuiper Kip bij Grubbenvorst). ${ }^{16}$ De bouw van hun vleeskuikenbedrijf 'in de korte keten' vordert gestaag. Uiteindelijk komen er stallen voor 960.000 vleeskuikens, een broederij en een slachterij. Dit is vanuit de vleeskuikenhouderij een megabedrijf, maar vanuit de kippenslachterij een microbedrijf. 'Een normale slachterij slacht 400.000 kuikens per dag, wij 32.000. ${ }^{17}$ De verwerkende stap organiseren is een probleem bij deelname aan de korte keten voor de vleeskuikenhouderij (zie figuur 8.1 en de opmerkingen daarbij met betrekking tot het korteketenconcept van Eric Veldhuisen). De vraag is of het bedrijf van de familie Kuipers gezien wordt als oplossing van dit probleem. Er is sprake van een korte keten in die zin dat er geen schakels meer zitten tussen uitbroeden, houden en slachten. De schaal is evenwel compleet anders dan veel mensen zich zullen voorstellen bij een korte keten. Het artikel gaat er overigens niet op in hoeveel schakels er zitten tussen houderij/slachterij en eindconsument.

\footnotetext{
14 https://www.novifarm.nl/

15 https://bramsfrites. nl/gourmet-frites

16 https://www.pluimveeweb.nl/artikel/196720-bouw-korte-keten-kuijpers-kip-vordert

17 https://www.nrc.nl/nieuws/2015/04/04/ruim-18x-deze-kippenstal-1480885-a1368711
} 


\section{Enkele aanvullende kenmerken van bedrijven die actief zijn in korte ketens}

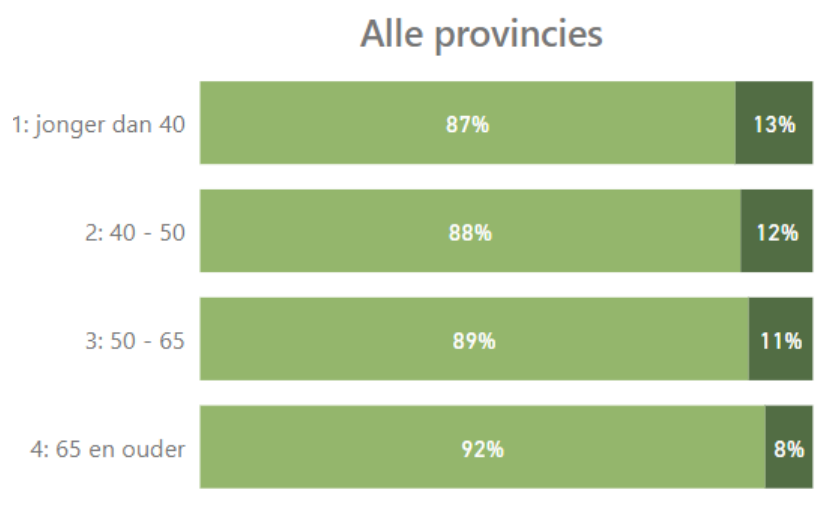

Relatief

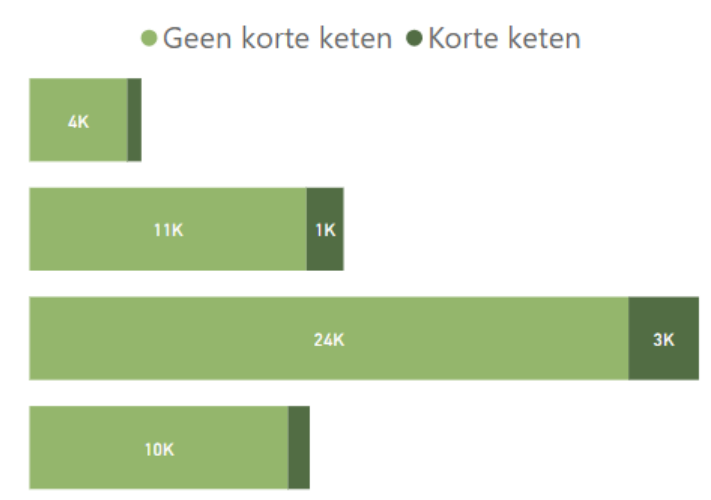

Absoluut

Figuur 11.1 Aandeel korteketenbedrijven per leeftijdscategorie

Uit figuur 11.1 blijkt dat jongere ondernemers (jonger dan 40 jaar) relatief vaker via korte ketens leveren. Absoluut gezien zijn er evenwel meer oudere boeren (tussen 50 en 65) die in korte ketens participeren. Dit komt omdat er gewoon veel meer oudere boeren in Nederland zijn dan jongere boeren.

Als je beleidsinstrumenten richt op het professionaliseren van korte ketens is het verleidelijk je alleen te richten op jongere boeren. Die zijn kennelijk immers meer bevattelijk voor korte ketens. Wil je echter veel impact maken, dan moet je je ook richten op de boeren van 50 tot 65 jaar (en van 40 tot 50 jaar). Dit is namelijk (in absolute zin) de grootste groep boeren die zich met korte ketens bezighoudt.

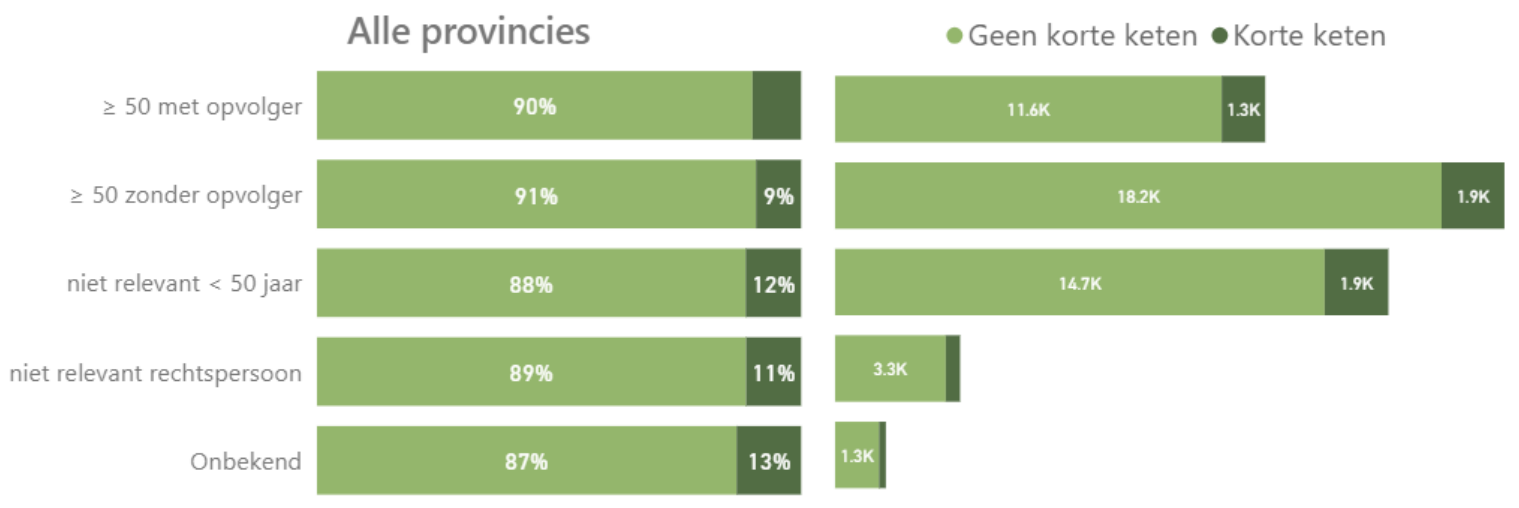

Relatief

\section{Absoluut}

Figuur 11.2 Aandeel korteketenbedrijven met of zonder bedrijfsopvolging 
Als we kijken naar de continuïteitssituatie dan lijkt het erop dat de bedrijfsopvolging geen invloed heeft op de beslissing of het bedrijf al dan niet in korte ketens actief is. Bedrijven met opvolger en zonder opvolger doen (ongeveer) evenveel aan korte ketens (figuur 11.2).

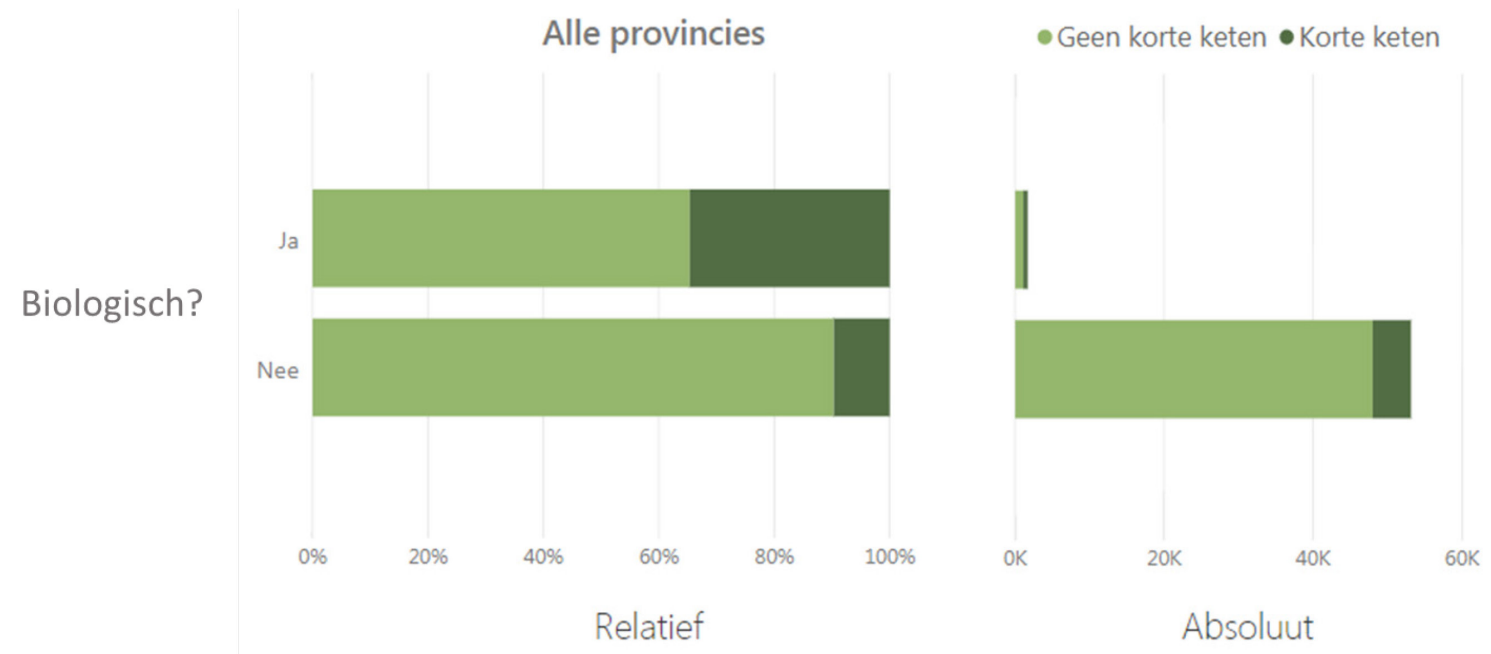

Figuur 11.3 Aandeel korteketenbedrijven in biologische sector

Uit figuur 11.3 blijkt dat 36\% van de biologische bedrijven levert via een korte keten. Dit terwijl slechts $10 \%$ van de gangbare bedrijven actief is in een korte keten. Er is dus een positief verband tussen biologische bedrijfsvoering en deelname aan korte ketens, maar er is zeker geen sprake van een-op-een overlap. Het meest interessante van deze cijfers is wellicht dat $64 \%$ van de biologische bedrijven niet levert in een korte keten. De biologische sector in Nederland is vooral gericht op de lange keten.

De 'local food'-beweging in de VS is juist opgekomen als kritiek op biologische bedrijven die ook daar meegingen in schaalvergroting en specialisatie, alsmede ketenverlenging die daar het gevolg van was (Pollan, 2016). Deze spanning tussen de biologische sector en de korteketensector is ook in Nederland merkbaar (zie ook Vijn et al., 2013). Biologische landbouw is helder gedefinieerd qua productieomstandigheden maar kan van grote afstand aangevoerd worden via een niet-gemaximeerd aantal tussenschakels. Korteketenlandbouw is minder helder gedefinieerd qua productieomstandigheden, maar is duidelijker geprofileerd qua smaak en kwaliteit, herkomst en transparantie (Vijn et al., 2013). Biologische landbouw gaat vanzelfsprekend uit van een premiumprijs die consumenten bereid zouden moeten zijn om te betalen, korteketenlandbouw wil in de meeste afzetkanalen qua consumentenprijs concurreren met gangbare landbouw. Zij proberen door ketenverkorting toch een hogere vergoeding voor de producent te realiseren, zonder dat dit ten koste gaat van toegankelijkheid voor brede groepen consumenten (geen hogere prijs voor consumenten).

Hoewel korte ketens relatief vaker voorkomen op biologische bedrijven dan op gangbare bedrijven, zijn er in absolute zin veel meer gangbare bedrijven dan biologische bedrijven en daarom zijn er in absolute zin veel meer gangbare bedrijven die in de korte keten actief zijn dan biologische bedrijven die in de korte keten actief zijn. Veel korteketeninitiatieven streven naar biologische productie in combinatie met korteketendistributie, maar komen voor sommige producten uiteindelijk bij gangbare korteketenbedrijven uit, omdat het volledig assortiment biologisch niet altijd aanwezig is in de regio. 


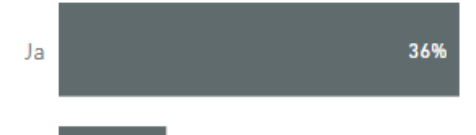

Nee

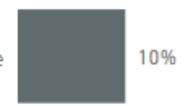

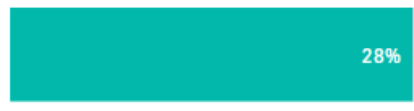

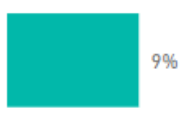

$-9 \%$

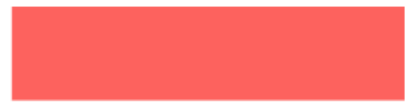

$-1 \%$

\section{Andere provincies}

Gelderland

\section{Verschil}

Figuur 11.4 Aandeel korteketenbedrijven in biologische sector Gelderland ten opzichte van rest van Nederland

Hoewel in heel Nederland $36 \%$ van de biologische bedrijven in een korte keten deelneemt, is dat aandeel in Gelderland maar 28\% (figuur 11.4). Met andere woorden: er zijn in Gelderland relatief veel biologische bedrijven die in lange ketens actief zijn. Dit heeft waarschijnlijk te maken met de exportoriëntatie van de biologische sector in Gelderland. Deze exportoriëntatie is vanuit het perspectief van de korte keten een aandachtspunt. Ook in Duitsland, een belangrijke exportmarkt voor biologische producten uit Nederland, neemt de roep om lokaal (en zo mogelijk biologisch) voedsel uit de korte keten toe. De markt voor biologische eieren uit Nederland is in Duitsland ingestort ten gevolge van de Fipronilcrisis. De Duitse consument geeft de voorkeur aan een in Duitsland geproduceerd ei. In Nederland zelf ondervinden biologische eieren concurrentie van het goedkopere 1-ster-beter-leven-ei. De biologische coöperatie Biomeerwaarde ${ }^{18}$ probeert onder andere door deelname aan de Masterclass Produceren in de Korte Keten Ede Barneveld op de Nederlandse markt door ketenverkorting een stevigere marktpositie te verwerven.

18 biomeerwaarde-ei.eu 


\section{Relatie korte ketens en verbrede landbouw}

Doet aan verbreding?
Excl. huisverkoop

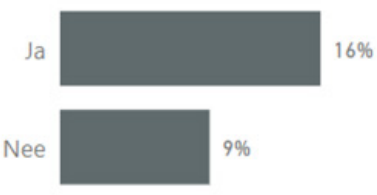

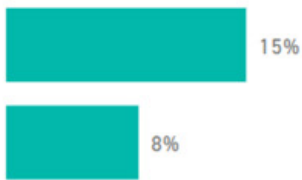

Figuur 12.1 Aandeel korteketenbedrijven in verbreding

Van de verbrede bedrijven (exclusief huisverkoop) heeft $16 \%$ een korte keten, van de louter op productie georiënteerde bedrijven (niet-verbreed) is slechts $9 \%$ in een korte keten actief. Er is dus een positieve relatie tussen korte ketens en verbreding. In de volgende paragrafen gaan we hier nog iets dieper op in.

Overige provincies

\section{Zorgboerderij}

\section{Educatie}

Kinderopvang

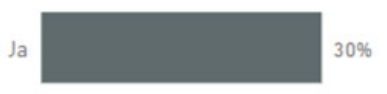

Nee
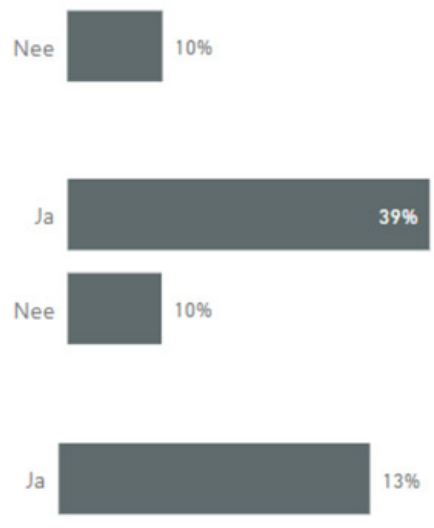

Nee
Gelderland
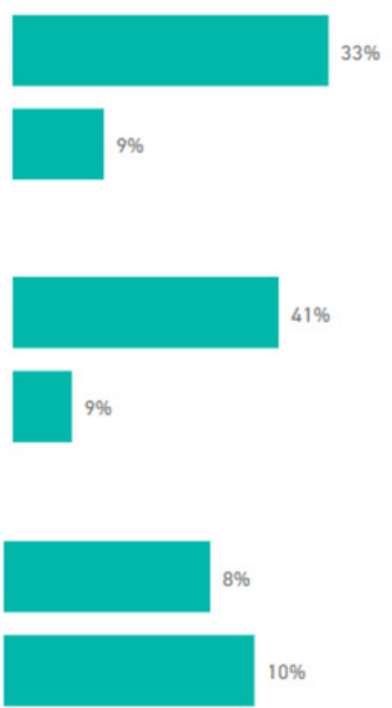

Figuur 12.2 Aandeel korteketenbedrijven in verbreding (2)

Er is een relatie tussen verbrede landbouw en korteketenlandbouw (zie figuur 12.1). De vraag is waar deze relatie precies op is gebaseerd. We hebben gekeken naar welk percentage van de zorgboerderijen in een korte keten participeert en dit vergeleken met het percentage bedrijven zonder zorg dat in een korte keten deelneemt (figuur 12.2). Deze percentages zijn respectievelijk $30 \%$ en $10 \%$. Er is dus een positief verband tussen het aanbieden van zorg en deelnemen in een korte keten. Voorstelbaar is dat zorgcliënten een rol kunnen spelen bij het uitvoeren van eenvoudige bewerkingen, zoals plukken, schoonmaken en verpakken. Activiteiten die het voor een landbouwbedrijf makkelijker maken om deel te nemen in een korte keten. Er zijn ook zorgboerderijen waar mensen met autisme de lokale distributie van boerderijproducten op zich nemen (persoonlijke communicatie Ard van de Kreeke, eigenaar van 't Hof Welgelegen, een korteketenleverancier in Zeeland).

Er is kennelijk ook een synergie tussen het bieden van educatie en leveren in de korte keten (figuur 12.2). Maar liefst 39\% van de bedrijven die aan educatie doet levert in een korte keten, terwijl slechts $10 \%$ van de bedrijven die niet aan educatie doet levert in korte ketens. Bedrijven zijn wellicht in staat via educatie meer mensen op het bedrijf te ontvangen c.q. meer mensen uit de regio met het 
bedrijf te laten kennismaken. En deze mensen rechtstreeks of via maximaal één tussenschakel van producten te voorzien. Beide combinaties (zorg en korte keten, educatie en korte keten) komen in Gelderland in gelijke mate voor als in de overige provincies. Bedrijven met kinderopvang leveren nauwelijks meer in korte ketens als bedrijven zonder kinderopvang (13\% respectievelijk $11 \%$ ). In dit geval is het verband voor Gelderland zelfs negatief. Er liggen hier wellicht kansen, om bijvoorbeeld ouders die hun kind komen ophalen tegelijkertijd van producten uit de korte keten te voorzien.

Van de boerenbedrijven die toeristische activiteiten aanbieden is $22 \%$ betrokken in korte ketens (figuur 12.3). Boeren die geen toeristen ontvangen zijn ook minder betrokken in korte ketens $(10 \%$ van de bedrijven). Er is dus een positief verband tussen het aanbieden van toerisme en betrokken zijn in korte ketens (zowel voor Gelderland als voor de overige provincies). Wat eigenlijk opvalt is dat dit verband niet veel groter is. Het ligt erg voor de hand dat wie toeristen op zijn bedrijf ontvangt die toeristen ook verleidt direct (of desnoods via een tussenschakel) producten van de boerderij te verkopen. Je zou verwachten dat dit bij een veel hoger percentage bedrijven het geval zou zijn. Mogelijk spelen restrictieve regels ten aanzien van huisverkoop een rol. Hier ligt volgens ons een grote potentie, vooral in gebieden in Gelderland waar veel toeristen op af komen (de Masterclass Rivierenland combineert het versterken van de korte keten met het ontwikkelen van een streekmerk).

Overige provincies

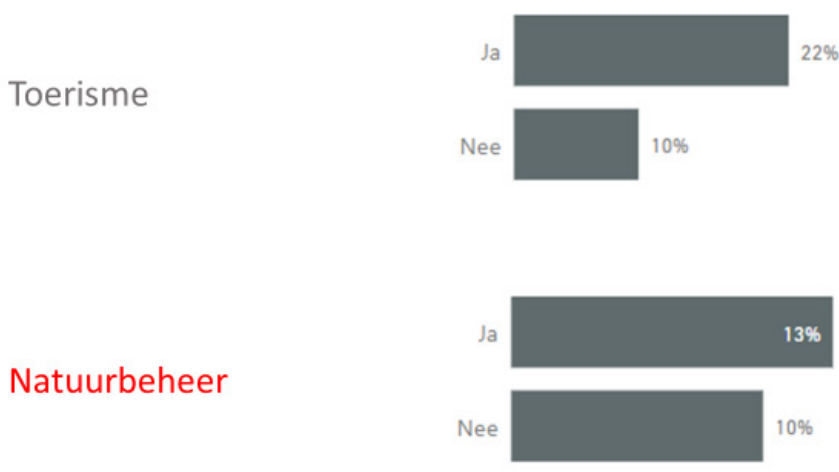

\section{Gelderland}
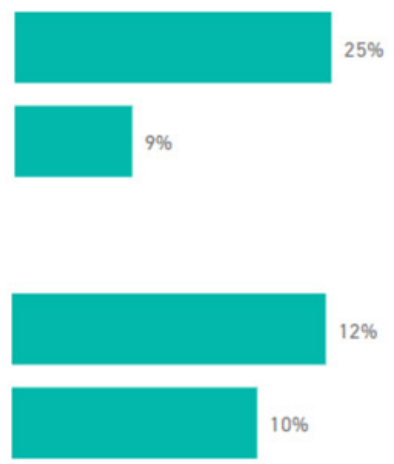

Figuur 12.3 Aandeel korte keten bedrijven in verbreding (3)

Van de boerenbedrijven die aan natuurbeheer doen verkoopt 13\% ook producten via de korte keten, terwijl van de bedrijven die niet aan natuurbeheer doen $10 \%$ producten verkoopt via de korte keten. $\mathrm{Er}$ is dus nauwelijks een positief verband tussen natuurbeheer en korte ketens (noch voor Gelderland, noch voor de overige provincies). Ook dit resultaat is opvallend, want je kunt je goed voorstellen dat een burger die geniet van boerennatuur ook geïnteresseerd zal zijn om ter plekke boerderijproducten te kopen uit die natuur (bijvoorbeeld het vlees van runderen of varkens die weiden in de door boeren beheerde natuurgebieden). Een deel van de natuur is niet voor recreatie, maar bijvoorbeeld extensieve beweiding voor vogelbeheer. Dat levert niet meteen die kansen op. Hoewel een aantal aansprekende voorbeelden van korte ketens in combinatie met natuurbeheer bekend zijn, is dit kennelijk een minder vaak voorkomende combinatie dan je op basis van de publiciteit zou mogen verwachten. Wellicht speelt de minder goed ontwikkelde regionale infrastructuur voor het slachten en be- of verwerking van het natuurvlees een rol. Hier ligt volgens ons ruimte voor ontwikkeling. Jos Bolk is voorzitter van de coöperatie Oregional en levert vlees van natuurkoeien via de korte keten. ${ }^{19}$ Ed Hendriks is als conceptontwikkelaar in vlees mede-initiatiefnemer van www. natuurvleesnederland.nl. Er zijn zo'n negentig Nederlandse boeren die hun runderen laten grazen in de vrije natuur waarvan EMTE het vlees als natuurvlees te koop aanbiedt. Door verkoop van EMTE aan Jumbo en Coop is de verkoop via EMTE-supermarkten recentelijk komen te vervallen en bezint Ed zich op andere verkoopkanalen, bijvoorbeeld via de groothandel (persoonlijke communicatie. Ed Hendriks).

19 www.naturkoeien.nl 


\section{Dynamiek korte ketens landelijk}

Tot slot van deze beschrijving en analyse van de korte ketens in de provincie Gelderland proberen we in kaart te brengen wat de dynamiek is in de korte keten. Neemt de omzet toe of af, welke sectoren en regio's binnen Gelderland groeien en welke krimpen? Het mag duidelijk zijn dat de projecten uit POP3 die als doel hebben korte ketens te stimuleren nog geen effect op de cijfers kunnen hebben. Die zijn immers in 2017 al verzameld terwijl de meest relevante POP3-projecten in Gelderland pas in 2018 en 2019 op stoom gekomen zijn.

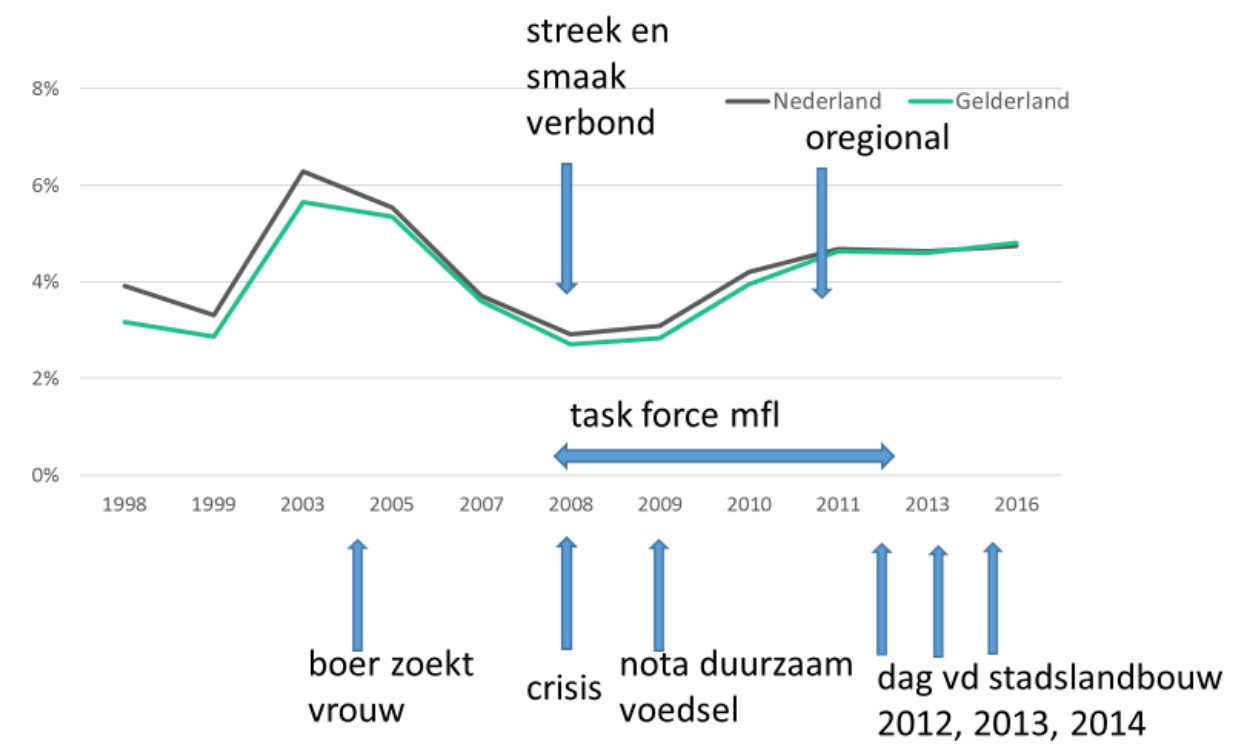

Figuur 13.1 Verandering percentage bedrijven met huisverkoop door de jaren heen

Omdat in 2017 voor het eerst de vraag over korte ketens werd gesteld, kunnen we op basis van deze Landbouwtelling geen goed beeld geven van de dynamiek per sector of regio. Wel zijn er eerder (2016, en 2013) vragen gesteld met betrekking tot multifunctionele landbouw, waaronder de directe verkopen van landbouwproducten aan de consument. Deze vragen worden in 2020 herhaald.

Figuur 13.1 toont dynamiek in de directe verkoop van landbouwproducten aan de consument. Vanaf 1999 stijgt de huisverkoop van 3\% tot bijna 6\% in 2003. Dan daalt de omzet weer tot 3\% in 2008. Vanaf 2009 stijgt de huisverkoop in Nederland (en Gelderland) van 3\% tot bijna 5\% in 2011, waarna ze afvlakt c.q. heel licht verder stijgt.

De vraag is hoe we dit verloop kunnen verklaren. Om de oordeelsvorming vanuit de praktijk te voeden hebben we deze vraag voorgelegd aan de deelnemers van de Masterclass Produceren in de Korte Keten Ede Barneveld en de Masterclass Rivierenland. Dit leverde als verklaringsgronden op: 'de crisis' (2008) en 'Boer zoekt vrouw' (vanaf 2004). Vanuit het beleid zijn er ook een aantal relevante initiatieven, hoewel korte ketens geen expliciet beleidsdoel waren: Nota Duurzaam Voedsel 2009 (minister Verburg) en Task Force Multi Functionele Landbouw 2008-2012. Daarnaast hebben we twee van rijkswege gesubsidieerde korteketeninitiatieven opgenomen: Streek en Smaak Verbond 2008 en Oregional 2011. Ten slotte hebben we een belangrijk congres ingetekend waar korteketeninitiatieven in Nederland een podium kregen en ervaringen werden uitgewisseld: Dag van de stadslandbouw 2012 Almere, Dag van de stadslandbouw 2013 Rotterdam en Dag van de stadslandbouw 2014 Den Bosch.

Alles overziend denken we dat de Task Force Multi Functionele Landbouw heeft bijgedragen aan de omzetontwikkeling in de huisverkoop vanaf de boerderij. Dit omdat de Task Force een infrastructuur creëerde waardoor kennis en ervaringen systematisch werden uitgewisseld en becommentarieerd, 
onder andere door regelmatige bijeenkomsten van het 'streekproducenten'-netwerk. Ook organiseerde de Task Force gemeenschappelijke behoeften, onder andere de behoefte aan een gedegen marktonderzoek naar de klantgroepen in Nederland die met name geïnteresseerd zouden zijn in wat toen nog streekproducten heette (Motivaction, 2009). ${ }^{20}$

Een andere plausibele verklaring voor het verloop van de grafiek is het uitbreken en het verloop van de financiële crisis in 2008. Deze crisis zou kunnen worden geduid als een belemmering voor de groei van korte ketens. Door de recessie hebben consumenten steeds minder te besteden. Dat kan een bedreiging zijn als het gaat om de aankoop van biologische streek/regioproducten. Overigens is dat in de afgelopen jaren niet gebleken; de afzetgroei van beide concepten gaat onverminderd door (Vijn et al., 2013). In de praktijk bleek de crisis dus wel degelijk samen te gaan met een groei van de directe verkoop aan consumenten. Dit valt waarschijnlijk te verklaren uit het feit dat mensen omdat ze minder te besteden hadden minder vaak buitenshuis gingen eten, maar daardoor juist meer geld overhielden om thuis te koken met kwalitatief goede ingrediënten met een verhaal (gekocht rechtstreeks bij de boer). Ook speelt een rol dat mensen de crisis wijten aan de ongecontroleerde krachten van globalisering, terwijl producten uit de korte keten juist staan voor regionale solidariteit en meer grip op je eigen toekomst.

De provincie Gelderland heeft als doelstelling voor de nabije toekomst ook de consumentenkant van het provinciaal voedsellandschap beter in kaart te brengen. Wie koopt via korte ketens, welke afzetkanalen zijn favoriet, wat zijn de trends? Het is op basis van de Landbouwtelling 2017 niet mogelijk hier meer duidelijkheid over te geven (buiten de trends rond huisverkoop). Consumentendata is niet altijd beschikbaar of alleen tegen hoge kosten toegankelijk, bijvoorbeeld supermarktkassadata worden in Nederland verzameld via IRI. ${ }^{21}$ Deze databank monitort aankoopgedrag op productniveau niet naar herkomst uit de korte of langere keten. Globaal marktonderzoek laat zien dat consumentenvertrouwen in globale merken laag is en producten met een gepersonaliseerde herkomst zich in toenemende populariteit mogen verheugen (ATKearney, 2017). Korte ketens passen in dit soort trends en de uitdaging is enerzijds intiem en vertrouwd te zijn, en anderzijds efficiënt en schaalbaar.

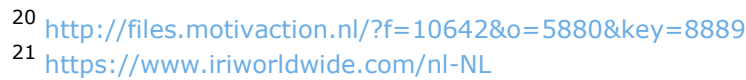




\section{Conclusies}

Het doel van het onderzoek was een beeld te geven van de korte ketens in de provincie Gelderland in 2017, vanuit het perspectief van de primaire bedrijven. Welke sectoren lopen qua omvang voorop: plantaardig, dierlijk, multifunctioneel, gespecialiseerd? Welke Gelderse regio's lopen qua omvang voorop: platteland of verstedelijkt? Wat is het beeld per gemeente? Een tweede doel was de resultaten te analyseren in het kader van de huidige beleidsthema's, zoals verwoord in de provinciale Omgevingsvisie en de Agenda Vitaal Platteland. Hoe zien de bedrijven eruit die zich met korte ketens bezighouden: grote of kleine bedrijven, oude of jonge ondernemers, al dan niet biologisch, veel bedrijven een beetje omzet via korte ketens of een paar bedrijven veel omzet. Een derde doel is inzicht te geven in de dynamiek van de korteketeneconomie. Welke sectoren hebben groei doorgemaakt, welke zijn stabiel gebleven of krimpen? Welke initiatieven zijn een succes, waar is sprake van teruggang, en hoe is dit te verklaren, en wat kunnen we hiervan leren?

Geconcludeerd kan worden dat de Landbouwtelling 2017 een goede basis biedt om het eerste en tweede doel van dit onderzoek te realiseren.

Eerste doel (wat en waar):

De sectoren die qua omvang vooroplopen zijn de fruitbedrijven, glasgroentebedrijven, leghenbedrijven voor consumptie-eieren, opengrondsgroentebedrijven, overige blijvende teelt bedrijven, en paddenstoelenbedrijven. De sectoren die achterlopen zijn de geitenbedrijven, melkveebedrijven, schapenbedrijven, vleeskalverenbedrijven, vleeskuikenbedrijven en vleesvarkensbedrijven. De verklaring die wij hiervoor geven is het feit dat sectoren met relatief weinig bewerkingen tussen productie en consumptie makkelijker via korte ketens kunnen leveren dan sectoren met relatief veel noodzakelijke bewerkingen, zoals slachten, melkbewerkingen, etc.

De Gelderse regio's met de grootste dichtheid qua omzet in korte ketens zijn Bommelerwaard en Betuwe, het gebied rond Barneveld, nabij Apeldoorn (Epe) en tussen Nijmegen en Arnhem (Lingewaard). De hoge concentratie in de Bommelerwaard zou te maken kunnen hebben met het beleid van Veiling Zaltbommel, dat expliciet gericht was op het ondersteunen van de korte keten. De hoge concentraties in Bommelerwaard, Betuwe en Rivierenland en rond Barneveld zouden te maken kunnen hebben met het karakter van de productie: fruit respectievelijk eieren behoeven geen verdere verwerking. Het product dat je oogst is het product dat je verkoopt. De hoge concentratie tussen Arnhem en Nijmegen alsmede nabij Apeldoorn zou te maken kunnen hebben met de stedelijke concentratie van koopkrachtige vraag in combinatie met een (hier en daar door verstedelijking enigszins) versnipperd platteland.

Tweede doel (wie):

\begin{tabular}{lll} 
Wel verband met korte ketens & Structuur & Multifunctioneel \\
& $\begin{array}{l}\text { Grotere bedrijven vaker } \\
\text { Ondernemers jonger dan } 40 \text { jaar vaker } \\
\text { In combinatie met biologisch }\end{array}$ & $\begin{array}{l}\text { In combinatie met zorg, educatie en } \\
\text { toerisme }\end{array}$ \\
\hline Geen verband met korte ketens & Opvolger aanwezig & Kinderopvang \\
& & Natuurbeheer
\end{tabular}

Hoewel biologische bedrijven en bedrijven die aan verbreding doen relatief vaker in korte ketens opereren dan gangbare bedrijven, komen deze combinaties minder vaak voor dan je zou verwachten. Dit komt omdat de biologische sector (in Nederland en in Gelderland) zich juist ook richt op de lange keten. Bedrijven met verbrede activiteiten zijn kennelijk niet altijd in staat het directere contact dat ze daardoor met eindconsumenten hebben, om te zetten in meer omzet via de korte keten (en vice versa). Ook verbrede landbouwbedrijven zijn kennelijk overwegend gericht op de lange keten. 
Derde doel (dynamiek):

De Landbouwtelling 2017 biedt momenteel geen goede basis om de derde doelstelling van dit onderzoek te verwezenlijken: in kaart brengen van de dynamiek (groei of krimp per sector of voor individuele initiatieven). Dit komt omdat de vraag naar korte ketens pas één keer gesteld is. Met betrekking tot huisverkoop is de vraag al wel vaker gesteld, als onderdeel van de vragen met betrekking tot verbreding (2013, 2016 en 2020). In de periode daarvoor werden gegevens met betrekking tot huisverkoop opgevraagd met een andere frequentie (2003, 2005, 2007-2011). Op basis van deze data lijkt van een grote stijging in de afzet via korte ketens geen sprake. Wel zijn een aantal factoren te noemen die korte ketens bevorderen. Vanaf 2009 stijgt de huisverkoop in Nederland (en Gelderland) van $3 \%$ tot bijna $5 \%$ in 2011 , waarna ze afvlakt c.q. heel licht verder stijgt. We denken dat de Task Force Multi Functionele Landbouw heeft bijgedragen aan de omzetontwikkeling in de huisverkoop vanaf de boerderij. Dit omdat de Task Force een infrastructuur creëerde waardoor kennis en ervaringen systematisch werden uitgewisseld en becommentarieerd, onder andere door regelmatige bijeenkomsten van het 'streekproducenten'-netwerk. Een andere plausibele verklaring voor het verloop van de huisverkoopgrafiek is het uitbreken en het verloop van de financiële crisis in 2008. Deze ging gepaard met een groei van de directe verkoop aan consumenten. Dit valt waarschijnlijk te verklaren uit het feit dat mensen omdat ze minder te besteden hadden minder vaak buitenshuis gingen eten, maar daardoor juist meer geld overhielden om thuis te koken met kwalitatief goede ingrediënten met een verhaal (gekocht rechtstreeks bij de boer). Ook speelt een rol dat mensen de crisis wijten aan de ongecontroleerde krachten van globalisering, terwijl producten uit de korte keten juist staan voor regionale solidariteit en meer grip op je eigen toekomst. 


\section{Aanbevelingen}

\section{Provincie Gelderland}

De omvang van de korteketensector in Gelderland in euro's is vergelijkbaar met de biologische sector, qua aantallen boeren is de korteketensector zelfs (veel) groter. Korteketeninitiatieven zijn, in de Gelderse regio's waar ze het meest voorkomen, geen stand-alone nicheprojecten die onderling geen impact op elkaars functioneren hebben. Maar het gaat om initiatieven die deel uitmaken of zouden kunnen uitmaken van plaatselijke of regionale clusters, waarbij die clusters (inmiddels of nog steeds) een significant aandeel in de plaatselijke of regionale economie hebben. Het beeld rijst op dat restanten van de regionale landbouw zoals die bestond voor de globalisering nog steeds bestaan en zich hebben weten te handhaven door aanpassing aan de nieuwe tijd. Daarnaast zijn er nieuwe initiatieven die gebruikmaken van nieuwe technologieën en nieuwe afzetkanalen zoals verkoop via internet en bezorging aan huis. De veelbesproken transitie naar een meer op de regio gerichte voedselvoorziening is in feite een beweging 'vooruit naar vroeger'. Dubbeling et al. spreken van Food System 1.0, waarbij sprake is van lokale en regionale productie en verwerking door kleinere producenten en ketenpartijen, Food System 2.0, waarbij er grotere afhankelijkheid is van internationale handel en sprake is van consolidatie bij productieverwerking en distributie, en Food system 3.0, met her-lokalisering van de voorzieningsketens, en nieuwe rollen voor de private sector: korte ketens, voedsel ICT platforms, gezondheid en volkshuisvesting (Dubbeling et al., 2016). Het Gelderse voedselsysteem bevindt zich, zo lijkt het, in deze derde fase. Het gaat niet om iets geheel nieuws, want voor de globalisering bestond er in veel delen van Nederland al een systeem van regionale voedselproductie, verwerking, distributie en consumptie. Maar het gaat ook niet om een terugkeer naar het oude (we gaan 'vooruit'). Want we kennen inmiddels ook de voordelen van de globale voedseleconomie, en die willen we behouden ('lokaal inkopen als het kan, globaal inkopen als het moet'). Nederland (inclusief Gelderland) heeft inmiddels ook een belangrijke exportpositie, die willen we niet koste wat kost behouden, maar ook niet zomaar negeren. Het gaat om een nieuwe balans tussen globaal en lokaal, niet om een verdringing van globaal door lokaal.

Als bovenstaand een correcte beschrijving van de uitgangssituatie in Gelderland is, dan moet de provincie zich qua innovatiebeleid (ondersteuning POP3, ondersteuning NV Oost) niet alleen richten op hippe start-ups, met een verhaal over de transitie in het voedselsysteem van globaal naar regionaal die op handen zou zijn. Maar ook moet de provincie zich richten op min of meer gangbare vaak regionaal opererende partijen die nooit zijn meegegaan in de globalisering, maar vaak door incrementele veranderingen zich hebben weten aan te passen aan de nieuwe tijd. Juist bij deze partijen zit de kennis hoe te overleven in een globaliserende voedseleconomie, en juist bij deze partijen zit vaak nog het volume om efficiënt te kunnen opereren en echt impact te hebben qua korteketendoelstellingen. Het is in dit verband tekenend dat juist in een periode dat korte ketens beleidsmatig op de provinciale agenda kwamen te staan, de veiling Zaltbommel haar beleid aanpaste en zich meer ging richten op lange ketens (de Greenery achterna, in plaats van het regionale alternatief te zijn voor de Greenery). De provincie moet zich daarom soms richten op vernieuwen, maar soms gaat het om behoud en herstel van wat ooit was. Denk aan het behouden (of herstellen) van regionale en plaatselijke verwerkende capaciteit: uit alles blijkt hoe belangrijk een fijnmazig netwerk van verwerkende schakels is. Denk ook aan regionale en plaatselijke logistieke infrastructuur: financier niet uitsluitend start-ups die een nieuwe afzetstructuur willen opbouwen uit het niets, maar kijk juist ook naar grow-ups die bestaande logistieke stromen willen bundelen en verdikken, zodat er kritische massa en efficiency ontstaat in plaats van versnippering en redundantie. Denk ook aan het behouden of herstellen van de regionale onderwijs- en kennisinfrastructuur rond korte ketens (zowel vers als licht bewerkt).

Het provinciaal innovatiebeleid moet zich daarbij eerder richten op het korteketencluster als geheel en minder op individuele projecten die daar min of meer los van staan. Kijk eerst goed wat de problemen per regio zijn (bijvoorbeeld gebrek aan verwerkende capaciteit, gebrek aan logistieke bundeling, fysieke afstand tot en bereikbaarheid van de consument, etc.) voordat je een bepaald initiatief 
ondersteuning biedt. Gelderland heeft er bij de POP3-regeling Samenwerking voor Innovaties voor gekozen de specifieke regionale en plaatselijke invulling via deelname van gemeenten te borgen, en dat is in principe een goede insteek. Maar sommige aspecten zijn plaats- en regio-overschrijdend, zoals alleen al blijkt uit het feit dat verschillende regio's binnen Gelderland zich hebben gespecialiseerd in bepaalde landbouwsectoren (bijvoorbeeld fruitteelt in de Betuwe, eierenproductie in Barneveld en melkveehouderij in de Achterhoek), waardoor samenwerking tussen die regio's voor de hand ligt om te komen tot een breed samengesteld menu uit de korte keten. De Gelderse regeling stimuleert de samenwerking tussen gemeenten (je kunt een groter budget aanvragen als meer gemeenten meedoen). Maar voor samenwerking op een schaal die de provincie overstijgt (bijvoorbeeld logistieke samenwerking om landelijk opererende supermarktketens te bedienen) is het aanvragen van gelijktijdige ondersteuning vanuit diverse provincies vrijwel onmogelijk. Hierdoor komen provincieoverstijgende korteketeninitiatieven niet voor ondersteuning in aanmerking, hoewel het om grow-ups zou kunnen gaan die juist de kritische massa hebben om het serviceniveau richting afnemers te vergroten en schaalvoordelen te realiseren.

Naast het stimuleren van (plattelands)innovatie, hebben provincies ook een rol in het integreren van het korteketenperspectief in de ruimtelijke ordening. Het is duidelijk dat korte ketens zich niet gelijkmatig over Gelderland verdelen, ze komen op en floreren, of leiden een kwijnend bestaan, ook vanwege locatie-specifieke factoren, die voor een deel gegeven zijn, maar voor een deel ook door beleid beïnvloedbaar. Provincies moeten samen met gemeenten en andere gebiedspartijen komen tot een visie op de inrichting van het provinciaal, regionaal en lokaal voedsellandschap en de rol van de korte keten (de regionale voedseleconomie) in dat landschap. Waar stimuleren we huisverkoop, waar kiezen we voor gezamenlijke verkoop via andere kanalen zoals bv. markten (en ontlasten daarbij het platteland qua vervoersbewegingen)? Waar plaatsen we verwerkende capaciteit: op het boerenerf of op het industrieterrein, individueel of gezamenlijk geëxploiteerd? Waar herstellen we of realiseren we een nieuwe lokale of regionale food hub: een groothandelsterrein speciaal ingericht voor korte ketens? Hoe helpen we steden om te komen tot efficiënte stadsdistributie (samenwerken rond binnenstedelijke logistiek rond de 'last mile')?

\section{Rijk}

De belangrijkste aanbeveling voor het Rijk is korte ketens als een expliciete beleidsdoelstelling op te nemen ook voor Nederland in het nieuw te formuleren Nationaal Strategisch Plan in het kader van het Gemeenschappelijk Landbouw Beleid. Korte ketens zijn geen doel op zich maar een belangrijk middel om andere beleidsdoelstellingen effectiever te behalen. Dit omdat boeren en consumenten in korte ketens een minder grote afstand tot elkaar hebben, zowel fysiek als mentaal. Hierdoor is het voor een boer makkelijker om helderheid te geven over zijn productiewijze en verantwoording af te leggen over gemaakte keuzen daar waar burgers concrete vragen hebben. Anderzijds is het voor een consument makkelijker om dit soort vragen te stellen en begrip op te brengen voor de door de boer gemaakte keuzen. Dit komt niet in de plaats van formele verantwoording en controle maar is er complementair aan. Duidelijk is ook (zo blijkt uit de door Gelderland medegefinancierde Masterclasses Produceren in Korte voorzieningsketens) dat korte ketens vaak een bakermat zijn voor innovaties. Dit omdat de terugkoppeling van percepties en ervaringen niet via marktonderzoeksbureaus, productontwikkelingsafdelingen en inkoopvoorwaarden richting toeleverende boeren bedrijven loopt, maar rechtstreeks plaatsvindt van consument naar boer en vice versa. Juist dit directe contact maakt innovatie mogelijk: betere kennis van achterliggende motieven, kortere cycli van testen, terugkoppelen, aanpassen en opnieuw proberen. Dit is een niet te onderschatten rol van korte ketens voor een landbouwnatie als Nederland. Kortere ketens zijn een kraamkamer voor vernieuwing, ook voor langere ketens.

In 2017 is voor het eerst gevraagd naar de omzet van korte ketens volgens de nieuwe definitie van de EU, dus niet slechts huisverkoop maar breder: elke vorm van verkoop met maximaal één tussenschakel. We bevelen aan deze nieuwe definitie vaker te hanteren, in een eventueel vervolg voor latere jaren en richting andere provincies. De nieuwe definitie laat zien dat het gaat om een economische sector met een relevante omvang en veelzijdigheid. Deze definitie erkent ook het belang van verwerkende schakels. Uit onderhavig onderzoek blijkt immers dat het ontbreken van verwerkende schakels daar waar de aard van het product die wel nodig heeft, een belangrijke verklaring is voor het succes van korte ketens. Een aanbeveling aan het Rijk is om, samen met de 
andere provincies, het landelijk beeld qua korteketenomzet compleet te maken. Op deze manier ontstaat een nulmeting die kan dienen als onderbouwing voor een meer systematische ondersteuning van korte ketens in het landelijk en regionaal landbouwbeleid.

Uit onderhavig onderzoek blijkt wel dat er (in theorie en) in de praktijk nog onduidelijkheid heerst over wat precies een korte keten is en wat niet. Telt een tussenschakel die in juridische zin afgescheiden is maar in praktische zin economisch verbonden is met de bedrijfsvoering van primaire producenten mee als tussenschakel voor de definitie of niet? Of kiezen we in Nederland voor de meer complexe inhoudelijke definitie van korte ketens: gebaseerd op partnerschap en transparantie (EIP AGRI 2015)? Het gaat immers om de herwaardering, zowel maatschappelijk als economisch, van de bijdrage van boeren aan de voedselvoorziening?

Moeten we dan niet juist ook in de wereld van korte ketens transparantie stimuleren en waarborgen inbouwen dat partijen doen wat ze beloven (en daadwerkelijk een hogere marge gunnen aan de deelnemende boeren)? Transparantie rond de verdeling van de marge is aan de orde in lange ketens, maar juist ook in korte ketens. Het is niet praktisch uitvoerbaar voor elke consument als hij individueel moet controleren of boeren in korte ketens daadwerkelijk een eerlijkere prijs krijgen. Initiatieven die dit probleem van transparantie op effectieve en efficiënte wijze oplossen verdienen daarom ondersteuning. Denk aan retailers die volledige transparantie nastreven zoals supermarkt HISBE (How It Should Be) in Brighton UK. ${ }^{22}$ Kan transparantie worden opgenomen als formele eis in de definitie van de korte keten?

\section{Provincies en Rijk}

Korte ketens zijn geen doel op zich maar een middel om andere doelen efficiënter of effectiever te kunnen behalen. Het idee is dat ondernemers via korte ketens bij de eindconsument (of inkoper) begrip kunnen vragen voor extra inspanningen die ze gedaan hebben maar waarvan de erkenning nog niet gestandaardiseerd is via sectorbrede keurmerken of certificaten. Uit de data blijkt dat er inderdaad een positief verband is tussen korte ketens en maatschappelijke doelen zoals deze geëxpliciteerd zijn voor biologische landbouw en verbrede landbouw. Toch denken wij dat het potentieel nog onvoldoende benut is. Denk aan kinderopvang en natuurbeheer, maar ook de andere vormen van verbrede landbouw zijn minder gecorreleerd met korte ketens dan te verwachten was. We pleiten dus voor het organiseren van kennisuitwisseling op landelijk en provinciaal niveau rond korte ketens en natuurbeer en rond korte ketens en andere vormen van verbrede landbouw. We pleiten ook voor kennisuitwisseling tussen de korteketensector en de biologische sector. Korte ketens worden vaak geassocieerd met duurzame landbouwpraktijken maar noch de boven gehanteerde definitie noch de dagelijkse praktijk waarborgen dat korte ketens altijd gericht zijn op meer duurzame landbouwpraktijken. De korteketensector kan van biologische landbouw leren hoe duurzaamheidsgaranties gedefinieerd en geborgd kunnen worden. De biologische landbouw kan van de korteketensector leren in termen van seizoensgebondenheid, en (informele) transparantie.

22 https://hisbe.co.uk 


\section{Literatuur en websites}

Dubbeling, M., J. Carey en K. Hochberg (2016). The role of private sector in city region food systems. Part I: Analysis report. RUAF Foundation and FBKN

EIP-AGRI (2015). Focus Group on Innovative Food Supply Chain Management: Final report

Galli, F. en G. Brunori (Eds.) (2013). Short Food Supply Chains as drivers of sustainable development, Evidence Document. Document developed in the framework of the FP7 project FOODLINKS (GA No. 265287). Laboratorio di studi rurali Sismondi, ISBN 978-88-90896-01-9

Kearny, A.T. (2017). Global Future Consumer Study, The consumers of the future: Influence vs. Affluence

Pollan, M. (2011). The Omnivore's Dilemma, The Search for a Perfect Meal in a Fast-Food World, Bloomsbury Publishing Plc

Rijk, C. van (2011). De versmarkt in kaart, Een verkennend onderzoek naar de voedselketen van de reguliere versmarkten in vier Brabantse steden en hun potentieel voor grotere regionale verankering. Master Thesis Wageningen Universiteit

Van der Schans, J.W. en S. Klein Gebbink (2014). Regionaal voedsel in Arnhem, Naar meer regionaal voedsel in Arnhem, Wetenschapswinkel, rapport 303

Vijn, M., M. Schoutsen, A. Monteny en A. Visser (2013). Zijn streekproducten een kans of bedreiging voor de biologische sector? PPO nr. 559, PPO - Wageningen UR

Wiskerke, J.S.C. (2009). On Places Lost and Places Regained: Reflections on the Alternative Food Geography and Sustainable Regional Development, International Planning Studies 14(4) -369387, DOI: $10.1080 / 13563471003642803$

Wolff Schoemaker, F., F. Woldhek, A. Mees en F. Spangenberg, (2009). Het marktpotentieel van streekproducten, Op zoek naar de juiste lading, doelgroep en afzetkanalen. Onderzoeksrapportage Motivaction, Projectnummer M4245 
Wageningen Economic Research Postbus 29703

2502 LS Den Haag

T 0703358330

Ecommunications.ssg@wur.nl

www.wur.nl/economic-research

Wageningen Economic Research NOTA

2019-072
De missie van Wageningen University \& Research is 'To explore the potential of nature to improve the quality of life'. Binnen Wageningen University \& Research bundelen Wageningen University en gespecialiseerde onderzoeksinstituten van Stichting Wageningen Research hun krachten om bij te dragen aan de oplossing van belangrijke vragen in het domein van gezonde voeding en leefomgeving. Met ongeveer 30 vestigingen, 5.000 medewerkers en 10.000 studenten behoort Wageningen University \& Research wereldwijd tot de aansprekende kennisinstellingen binnen haar domein. De integrale benadering van de vraagstukken en de samenwerking tussen verschillende disciplines vormen het hart van de unieke Wageningen aanpak. 



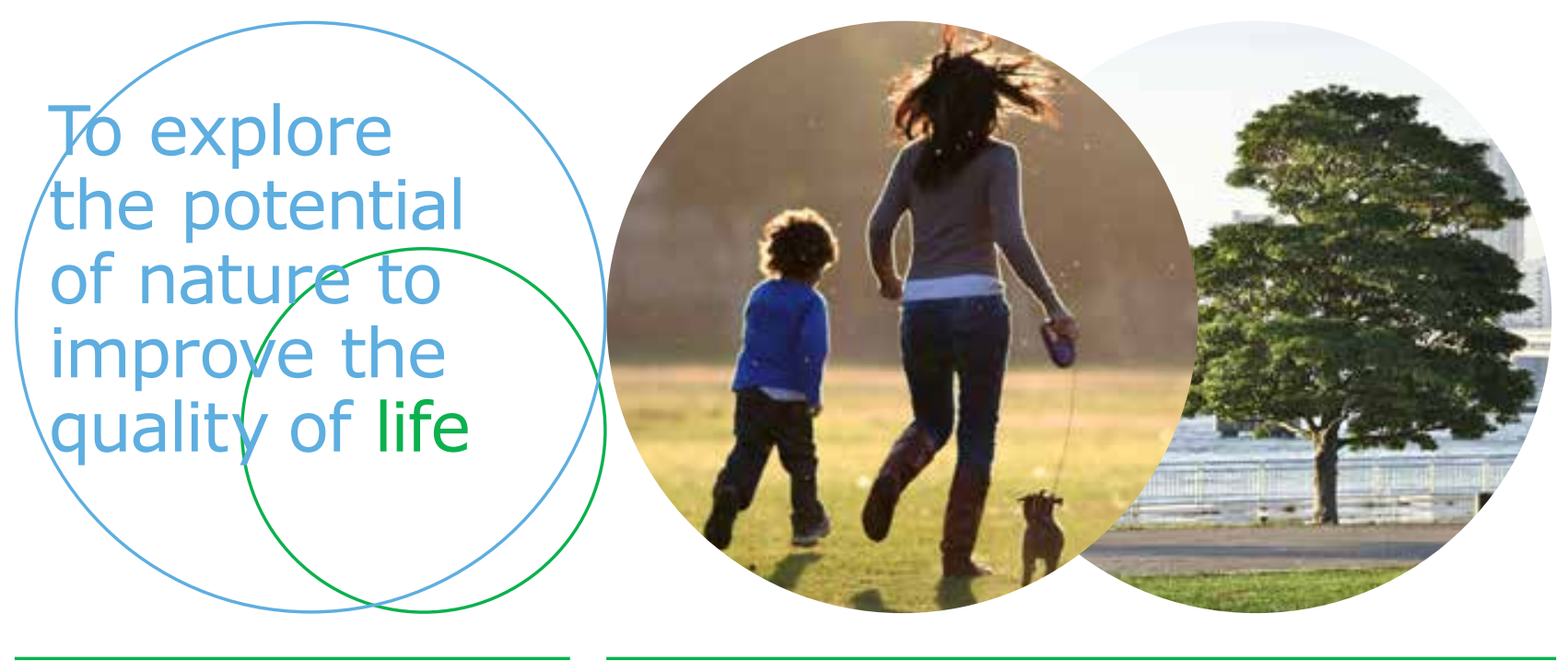

Wageningen Economic Research Postbus 29703

2502 LS Den Haag

E communications.ssg@wur.nl

T+31(0)7033583 30

www.wur.nl/economic-research

Nota 2019-072
De missie van Wageningen University \& Research is 'To explore the potential of nature to improve the quality of life'. Binnen Wageningen University \& Research bundelen Wageningen University en gespecialiseerde onderzoeksinstituten van Stichting Wageningen Research hun krachten om bij te dragen aan de oplossing van belangrijke vragen in het domein van gezonde voeding en leefomgeving. Met ongeveer 30 vestigingen, 5.000 medewerkers en 10.000 studenten behoort Wageningen University \& Research wereldwijd tot de aansprekende kennisinstellingen binnen haar domein. De integrale benadering van de vraagstukken en de samenwerking tussen verschillende disciplines vormen het hart van de unieke Wageningen aanpak. 